\title{
A $\beta$ Oligomer-Induced Aberrations in Synapse Composition, Shape, and Density Provide a Molecular Basis for Loss of Connectivity in Alzheimer's Disease
}

\author{
Pascale N. Lacor, Maria C. Buniel, Paul W. Furlow, Antonio Sanz Clemente, Pauline T. Velasco, Margaret Wood, \\ Kirsten L. Viola, and William L. Klein \\ Department of Neurobiology and Physiology, Northwestern University, Evanston, Illinois 60208
}

\begin{abstract}
The basis for memory loss in early Alzheimer's disease (AD) seems likely to involve synaptic damage caused by soluble $\mathrm{A} \beta$-derived oligomers (ADDLs). ADDLs have been shown to build up in the brain and CSF of AD patients and are known to interfere with mechanisms of synaptic plasticity, acting as gain-of-function ligands that attach to synapses. Because of the correlation between AD dementia and synaptic degeneration, we investigated here the ability of ADDLs to affect synapse composition, structure, and abundance. Using highly differentiated cultures of hippocampal neurons, a preferred model for studies of synapse cell biology, we found that ADDLs bound to neurons with specificity, attaching to presumed excitatory pyramidal neurons but not GABAergic neurons. Fractionation of ADDLs bound to forebrain synaptosomes showed association with postsynaptic density complexes containing NMDA receptors, consistent with observed attachment of ADDLs to dendritic spines. During binding to hippocampal neurons, ADDLs promoted a rapid decrease in membrane expression of memory-related receptors (NMDA and EphB2). Continued exposure resulted in abnormal spine morphology, with induction of long thin spines reminiscent of the morphology found in mental retardation, deafferentation, and prionoses. Ultimately, ADDLs caused a significant decrease in spine density. Synaptic deterioration, which was accompanied by decreased levels of the spine cytoskeletal protein drebrin, was blocked by the Alzheimer's therapeutic drug Namenda. The observed disruption of dendritic spines links ADDLs to a major facet of AD pathology, providing strong evidence that ADDLs in AD brain cause neuropil damage believed to underlie dementia.
\end{abstract}

Key words: ADDLs; dendritic spine; synaptosomes; NMDA-R; EphB2; memantine; drebrin

\section{Introduction}

Early Alzheimer's disease (AD) almost solely comprises severely dysfunctional memory (Terry et al., 1991; Selkoe, 2002; Coleman et al., 2004). This specificity likely is attributable to a vulnerability of particular memory-focused synapses to degeneration (Selkoe, 2002; Scheff and Price, 2003; Coleman et al., 2004), and synapse loss is considered to be the best correlate of AD dementia (DeKosky and Scheff, 1990; Terry et al., 1991; Sze et al., 1997). Recent evidence suggests that synapse degeneration begins at the level of dendritic spines, which are the loci of memory-initiating mechanisms (Harris and Kater, 1994; Morris and Davis, 1994; Carlisle and Kennedy, 2005; Segal, 2005). In AD and transgenic (Tg) mouse AD models, significant decreases occur in spine density

\footnotetext{
Received Aug. 11, 2006; revised Dec. 13, 2006; accepted Dec. 15, 2006.

This work was supported by the National Institutes of Health Grants AG018877 and AG022547 (W.L.K.) and AG022237 (P.N.L.), the Boothroyd Foundation, American Health Assistance Foundation-Alzheimer's disease research, and the Illinois Department of Public Health-Alzheimer's Disease Research Fund (P.N.L.). We are grateful to Dr. Mary Lambert for providing ADDL-derived antibodies, Daliya Khuon for her synaptosomal preparations, and Sara Fernandez for preparations of cultured neurons. Imaging was done at the Biological Imaging Facility of Northwestern University.

Correspondence should be addressed to either William L. Klein or Pascale N. Lacor, Department of Neurobiology and Physiology, Northwestern University, 0. T. Hogan Biological Sciences, Room 5-110, 2205 Tech Drive, Evanston, IL 60208. E-mail: wklein@northwestern.edu, p-lacor@northwestern.edu.

DOI:10.1523/JNEUROSCI.3501-06.2007

Copyright $\odot 2007$ Society for Neuroscience $\quad$ 0270-6474/07/270796-12\$15.00/0
}

(Ferrer and Gullotta, 1990; Moolman et al., 2004; Spires et al., 2005; Jacobsen et al., 2006) and in molecules involved in spine signaling (Sze et al., 2001; Mishizen-Eberz et al., 2004) and control of filamentous actin (F-actin) (Harigaya et al., 1996; Shim and Lubec, 2002; Counts et al., 2006). Conceivably, AD dementia may be initiated before synapse degeneration by spine aberrations. In fact, spine shape distortions are evident in other severe cognitive diseases such as mental retardation and prionoses.

Despite being of central importance to $\mathrm{AD}$ mechanisms, the molecules that trigger spine pathology are not known. Involvement of insoluble amyloid $\beta(\mathrm{A} \beta)$ fibrils has long been favored, but abnormal neuropil in $\mathrm{AD}$ can occur in the absence of contiguous amyloid plaques (Einstein et al., 1994; Lue et al., 1999; Coleman et al., 2004). In Tg mouse AD models, synapse abnormalities as well as memory impairments correlate poorly with plaque burden and can occur before plaque formation (Holcomb et al., 1999; Hsia et al., 1999; Larson et al., 1999; Mucke et al., 2000; Jacobsen et al., 2006). Antibodies against A $\beta$ prevent synapse degeneration in Tg mice (Buttini et al., 2005), but memory impairment is reversed without loss of plaques (Dodart et al., 2002; Kotilinek et al., 2002). Thus, a toxin from $A \beta$, not present in plaques, would appear to be responsible for synapse degeneration.

$\mathrm{AD}$ brains also contain small neurotoxins that comprise soluble A $\beta$ oligomers (Gong et al., 2003; Kayed et al., 2003; Lacor et 
al., 2004), which have been called $\mathrm{A} \beta$-derived diffusible ligands (ADDLs) (Lambert et al., 1998). ADDL-triggered neuronal damage is now recognized as a central feature of AD pathology (Rodgers, 2005; Standridge, 2006). Because ADDLs are gain-offunction ligands that target synaptic spines (Lacor et al., 2004; Klein et al., 2007) and disrupt synaptic plasticity (Lambert et al., 1998; Wang et al., 2002), their cellular actions may be particularly germane to neuropil damage (Klein et al., 2001; Klein, 2006). This possibility is supported by findings that ADDLs induce abnormal expression of Arc (Lacor et al., 2004), a synaptic memoryrelated protein, in a manner predicted to cause abnormal spine shape and receptor trafficking (Lacor et al., 2004; Klein, 2006). The current study has tested the impact of ADDLs on spines using mature hippocampal neuron cultures, a preferred model for studies of synapse cell biology (Boyer et al., 1998). Abnormalities induced by ADDLs in spine composition, shape, and abundance strongly support the hypothesis that ADDLs in AD brains initiate toxic mechanisms underlying neuropil damage.

\section{Materials and Methods}

ADDL preparation and fractionation. $\mathrm{A} \beta_{1-42}$ peptide (California Peptide Research, Napa, CA or American Peptide, Sunnyvale, CA) or biotin$\mathrm{A} \beta_{1-42}$ peptide (Recombinant Peptide, Athens, GA) were used to prepare synthetic ADDLs and biotinylated ADDLs according to published protocols (Lambert et al., 2001; Klein, 2002). A $\beta_{1-40}$ peptide was purchased from rPeptide (Bogart, GA). Ultrafiltration of ADDLs and A $\beta_{1-40}$ preparations were done using either Nanosep 10K omega (Pall Corporation, Ann Arbor, MI) or Microcon YM-50 (Amicon, Bedford, MA), according to the instructions of the manufacturer.

Hippocampal cell culture and treatments. Mature hippocampal cell cultures [at least 21 days in vitro (DIV)] were prepared as described previously (Lacor et al., 2004) and treated with $500 \mathrm{~nm}$ ADDLs or equivalent volume of F-12-vehicle for various incubation times. $A \beta_{1-40}$ prepared in DMSO, filtrates, and retentates obtained by 10 and $50 \mathrm{kDa}$ cutoff filters were added to the cell culture at a final concentration of $500 \mathrm{~nm}$. The uncompetitive NMDA receptor (NMDA-R) antagonist memantine (3,5dimethyl-amantadine hydrochloride) (Sigma, St. Louis, MO) was added to cell culture media, at the final concentration of $5 \mu \mathrm{M}, 30$ min before ADDL or vehicle treatment. An equivalent volume of sterile distilled water was used as a control for the memantine treatment. ADDLsensitive neurons in the vehicle-treated group were identified by exposing the cells to ADDLs for 5 min before fixation.

Immunocytochemistry. Treated cells were rinsed to remove unbound ADDLs and then fixed with $3.7 \%$ formaldehyde or $4 \%$ paraformaldehyde in Neurobasal media (1:1 volume) for 20 min followed by an additional 20 min undiluted fixative. Cells were rinsed extensively in PBS. Coverslips were incubated in blocking solution (10\% NGS in PBS with or without $0.1 \%$ Triton X-100) for $45 \mathrm{~min}$ at room temperature (RT). Antibodies were used against the following proteins: NMDA-R1 and NMDA-R2B, EphB2 (Santa Cruz Biotechnology, Santa Cruz, CA); drebrin (Stressgen, Victoria, British Columbia, Canada); A $\beta$ species (6E10; Senetek, St. Louis, MO) and ADDLs (M94 or NU-2) (Lambert et al., 2001, 2007); spinophilin (Upstate Biotechnology, Lake Placid, NY); and glutamic acid decarboxylase (GAD) 65/67 (Sigma). Primary antibodies were diluted in blocking solution and incubated overnight at $4^{\circ} \mathrm{C}$. After rinses with PBS with $1 \%$ NGS, coverslips were incubated with appropriate Alexa-conjugated secondary antibodies (Invitrogen, Carlsbad, CA) diluted in PBS plus 1\% NGS for 90 min at RT, rinsed extensively in PBS, and mounted with ProLong Anti-fade media.

Image acquisition and analysis. ADDL-bound neurons and dendritic branches were imaged using a Leica (Exton, PA) TCS SP2 laser confocal microscope with laser intensity and signal detection settings held constant to allow for quantitative comparison between experimental groups. Optical serial sections of $0.5 \mu \mathrm{m}$ intervals were taken through the cells and reconstructed to generate a maximum intensity projection of $z$-stack images from individual cells and dendritic branches. Five neurons per experimental group were captured per experiment, and data from two or three independent experiments were pooled for analysis. After distance calibration and intensity threshold, one to two dendritic segments from each neuron were used to determine spine density and length. Spine density was automatically calculated by dividing the counted number of spines per measured dendrite length. Spines were counted manually using MetaMorph software version 6.3 (Universal Imaging Corporation, Downingtown, PA). Spines were defined as protrusions that could be differentiated from the dendritic shaft and restricted to those that were visible in the $x$-and $y$-axes. The length of spines was quantified manually using the line segment tool in MetaMorph software; briefly, a line was drawn from the limit of the dendritic shaft (base) to the tip of the protrusions (head) and then ultimately binned into different categories with $0.5 \mu \mathrm{m}$ intervals. All spine measurements were made on $z$-stack images of dendritic segments. Surface receptor puncta were identified using threshold held at a constant level for all images within an experiment and then analyzed using the "integrated morphometry" feature after setting the standard object size. Receptor density was obtained by dividing the number of surface receptors by the length of the dendrite within a selected dendritic region. Drebrin immunofluorescence in randomly selected ADDL-targeted neurons from four different experiments was measured after "despeckle" noise reduction and background subtraction using NIH ImageJ $1.36 \mathrm{~b}$ software. Integrated density measurement represents the sum of the gray values of all of the pixels in the selection divided by the number of pixels. Values are relative to the vehicle-treated controls set at $100 \%$. All data are depicted as mean \pm SEM. All data were analyzed by GraphPad (San Diego, CA) Prism4 software for statistical significance using one-way ANOVA and, if overall $p<0.05$, followed by a multiple group comparison post hoc test (Tukey's) in which $p<0.05$ was the minimum level of significance.

Synaptosome preparation, treatment, and immunoprecipitation. Synaptosomes were prepared from rat forebrain as described by Dodd et al. (1981) and for comparison of binding to forebrain versus cerebellar synaptosomes as described by Raiteri's protocol (Raiteri and Raiteri, 2000). Synaptosomes $(75 \mu \mathrm{g})$ were treated with $300 \mathrm{~nm}$ ADDLs or vehicle in buffer A (PBS, pH 7.4, and 5\% FCS) overnight at $4^{\circ} \mathrm{C}$ on a rotator. Free ADDLs were removed by washing with buffer $\mathrm{A}$ and centrifugation at $6000 \times g$ for $10 \mathrm{~min}$. Dynabeads (M-500 subcellular; Invitrogen) were coated with secondary antibody (goat anti-rabbit or anti-mouse IgG Fc fragment; Jackson ImmunoResearch, West Grove, PA) according to the directions of the manufacturer. Immunoprecipitation was done using anti-rabbit IgG Dynabeads preincubated with anti-ADDL antibody (M71/2, $\sim 5 \mu \mathrm{g} / \mathrm{mg}$ beads). Treated synaptosomes were suspended in 300 $\mu \mathrm{l}$ of buffer $\mathrm{A}$ and incubated with washed M71/2-coupled Dynabeads (1 $\mathrm{mg}$ ) overnight at $4^{\circ} \mathrm{C}$ on a shaker. Beads were recovered with a magnet, extensively washed in buffer and then PBS. Supernatant collected represented "unbound" and "wash" fractions, whereas the pellet corresponded to the "bound" fraction. Unbound and wash fractions were centrifuged at $20,000 \times g$ for $20 \mathrm{~min}$; the pellets were dissolved in $60 \mu \mathrm{l}$ of Laemmli sample buffer for Western blot analysis. Samples $(15 \mu \mathrm{l})$ were loaded on a $4-20 \%$ Tris-glycine gel (Invitrogen), electrophoreted with Tris-glycine SDS buffer, transferred onto nitrocellulose membrane, and immunoblotted for postsynaptic density-95 (PSD-95) (1:4000, MA1045; Affinity BioReagents, Golden, CO) and synaptophysin (1:2000, SVP-38; Sigma). Signal was visualized using horseradish peroxidaselinked secondary antibody (Amersham Biosciences, Buckinghamshire, UK) and developed with ECL substrate (SuperSignal West Femto Maximum Sensitivity substrate; Pierce, Rockford, IL). Fractionation of ADDL-bound synaptosomes was done according to Phillips's method (Phillips et al., 2001). Proteins were measured in synaptic junctions, PSDs, and active zones and analyzed by Western blot under reducing conditions or dot blot using antibodies against ADDLs (NU-1), PSD95, and synaptophysin. For coisolation of synaptic proteins and ADDLs, synaptosomes $(2 \mathrm{mg}, 0.5 \mathrm{mg} / \mathrm{ml})$ treated with $300 \mathrm{~nm}$ ADDLs in PBS for $1 \mathrm{~h}$ at $37^{\circ} \mathrm{C}$ were centrifuged at $6000 \times g$ for $10 \mathrm{~min}$ at $4^{\circ} \mathrm{C}$ and washed. The washed synaptosomes were resuspended to $1 \mathrm{mg} / \mathrm{ml}$ in PBS with 2.5 $\mu \mathrm{g} / \mathrm{ml} \mathrm{NU}-2 \mathrm{IgG}$, incubated on a rotator for $1 \mathrm{~h}$ at $4^{\circ} \mathrm{C}$, centrifuged, and washed. Synaptosomes resuspended in PBS and $0.2 \%(\mathrm{v} / \mathrm{v})$ Triton X-100 were incubated on ice for $30 \mathrm{~min}$, deoxycholic acid (DOC) was added to $0.1 \%(\mathrm{w} / \mathrm{v})$, incubated for $30 \mathrm{~min}$ on ice, and then incubated with anti- 
mouse IgG Dynabeads ( $9 \mathrm{mg}$ ) overnight at $4^{\circ} \mathrm{C}$. The Dynabeads were extensively washed with 0 . $3 \mathrm{M} \mathrm{NaCl}, 1 \%$ Triton X-100, 0.5\% DOC in PBS, and then sequentially extracted for $10 \mathrm{~min}$ each with $120 \mu \mathrm{l}$ of $1 \%$ DOC at RT, $1 \%$ Sarkosyl on ice, and $1 \%$ Sarkosyl on ice. Finally, the Dynabeads were extracted with $120 \mu \mathrm{l}$ of $0.1 \%$ SDS at RT for $30 \mathrm{~min}$. Samples $(10 \mu \mathrm{l}$; unreduced or treated with $50 \mathrm{~mm}$ dithiothreitol at $100^{\circ} \mathrm{C}$ for $10 \mathrm{~min}$ ) were analyzed by SDS-PAGE Western blot with antibodies to ADDLs (M69-2, 1:2000), syntaxin (Millipore, Temecula, CA), PSD-95, NMDA 1 (NR1, 1:500; Santa Cruz Biotechnology), or NR2A/B (1:200; Millipore). Blots were visualized as described above.

Western blot analysis of drebrin. Treated cells were washed with culture medium and once with HBSS and then incubated with $500 \mu$ of PhosphoSafe extraction reagent (Novagen,

Madison, WI) for $5 \mathrm{~min}$ at RT and scraped from the dish. Lysates were centrifuged at $16,000 \times g$ for $5 \mathrm{~min}$ at $4^{\circ} \mathrm{C}$, and protein concentrations were measured in the supernatant by BCA protein assay kit (Pierce). Samples were mixed with Laemmli sample buffer, boiled for $5 \mathrm{~min}$, and loaded ( $\sim 5 \mu \mathrm{g}$ of protein per lane) in a $4-20 \%$ Tris-glycine SDS-PAGE gel for electrophoresis. Proteins were blotted to a nitrocellulose membrane (Hybond; Amersham Biosciences) for $1 \mathrm{~h}$ with transfer buffer (25 mM Tris, $192 \mathrm{~mm}$ glycine, 20\% methanol, and $0.02 \%$ SDS, pH 8.3). After a blocking step with $10 \%$ nonfat dry milk (NFDM) in PBS for $1 \mathrm{~h}$ at RT, the membrane was incubated with drebrin antibody (1:200; MBL, Nagoya, Japan) diluted in 1\% NFDM in PBS for $1 \mathrm{~h}$ at RT. For loading control, the membrane was blotted with cyclophilin antibody $(1: 10,000$; Affinity BioReagents) diluted in 5\% NFDM in TBST (Tris-buffered saline and $0.1 \%$ Triton X-100). After extensive washes with PBS, the membrane was incubated with HRP-conjugated anti-mouse or anti-rabbit IgGs (1:10,000; Amersham Biosciences) diluted in 1\% NFDM-PBS or TBST for $1 \mathrm{~h}$ at RT. After extensive washes, immunoreactive signal was revealed using ECL substrate, imaged, and quantified using the Kodak (Rochester, NY) IS440CF image station.

\section{Results}

\section{Characterization of ADDL-bound cells}

ADDL binding sites in mature hippocampal cultures were found on microtubule-associated protein-2-positive cells (data not shown) that express NMDA-R subunits NR1 and NR2B (Fig. $1 A, B)$. No clusters of bound ADDL were found on astrocytes (GFAP-positive cells; data not shown) or on inhibitory neurons expressing GAD (Fig. 1C). ADDLs bound predominantly to dendritic arbors and typically were not observed within neuritic or somatic cytoplasm, even under permeabilized conditions.

\section{ADDL-binding sites are present on postsynaptic sites}

We reported previously that ADDLs specifically colocalize with PSD-95 and target calcium/calmodulin-dependent kinase IIpositive protrusions (Lacor et al., 2004) likely to be excitatory synaptic spines. Dendritic spines are morphologically plastic protrusions, critical for synaptic information storage and memory, in which the majority of excitatory inputs occur. Additional evidence for specific binding of ADDLs to spines was provided by the immunofluorescence colocalization of ADDLs with drebrin (Fig. 2A), a cytoskeletal marker known to be concentrated within spine heads (Aoki et al., 2005). Synaptic localization indicated by microscopy was confirmed and extended by immunoprecipitation experiments in which synaptosomes were incubated with ADDLs and subjected to magnetic bead immunoprecipitation using ADDL-selective antibodies. Isolation of synaptosomes was monitored by assaying for the presence of PSD-95 (Fig. 2 B).
Synaptosomes from forebrain but not cerebellum were obtained by this procedure, indicating a regional specificity for binding consistent with previously observed ADDL toxicity (Kim et al., 2003). Pull-down was dependent on ADDL binding, because synaptic markers (PSD-95 and synaptophysin) were detected only in the bound fraction of ADDL-treated synaptosomes, not vehicletreated ones (Fig. $2 B$, inset).

Detergent extraction of synaptosomes with Triton X-100 and deoxycholate yielded an ADDL binding complex that still could be pulled down by immunobeads. The complex appeared to be postsynaptic because syntaxin, a presynaptic active-zone protein, remained in the unbound fraction (data not shown). Increased concentrations of Triton X-100 and deoxycholate did not release ADDLs from the beads, which required stronger detergents (Sarkosyl and SDS). The stronger detergents also released PSD-95 and the NR1 and NR2A/B subunits of NMDA receptors (Fig. 2C), markers of postsynaptic densities. To verify the apparent postsynaptic attachment of ADDLs, synaptic junctional complexes with bound ADDLs were subfractionated according to the procedure of Phillips et al. (2001). ADDLs were found to cosegregate with postsynaptic densities (PSD-95 positive) rather than presynaptic active zones (syntaxin positive) (Fig. $2 \mathrm{D}$ ). In a parallel ELISA assay, in which isolated PSDs or active zones were tested for their ability to bind ADDLs, only PSD-coated wells generated ADDL-immunoreactive signal (data not shown). Results from microscopy and biochemical fractionation thus are in harmony with the conclusion that ADDLs bind to excitatory synapses at postsynaptic sites, consistent with a putative ability to locally initiate dysfunction of hippocampal neuron synapses.

\section{Plasticity-linked receptors show decreased levels after ADDL exposure}

Preferential binding to excitatory synapses at postsynaptic sites is consistent with the inhibitory impact of ADDLs on NMDA-Rdependent long-term potentiation (LTP) (Lambert et al., 1998; Wang et al., 2002) and NMDA-R-mediated cAMP response element-binding protein (CREB) phosphorylation (Tong et al., 2001). Expression of Arc, a spine memory-linked protein that influences F-actin, also is disrupted by ADDLs (Lacor et al., 2004). The impact on Arc led to the prediction that synaptic ADDL binding would disrupt receptor trafficking and expression (Lacor et al., 2004; Klein, 2006). Here we tested whether ADDLs affect levels of NMDA-R, potentially providing a cellular mechanism that would contribute to the significant loss of NMDA-R in AD brain (Sze et al., 2001; Mishizen-Eberz et al., 2004). We also tested the effect of ADDLs on EphB2 receptors, which can be 


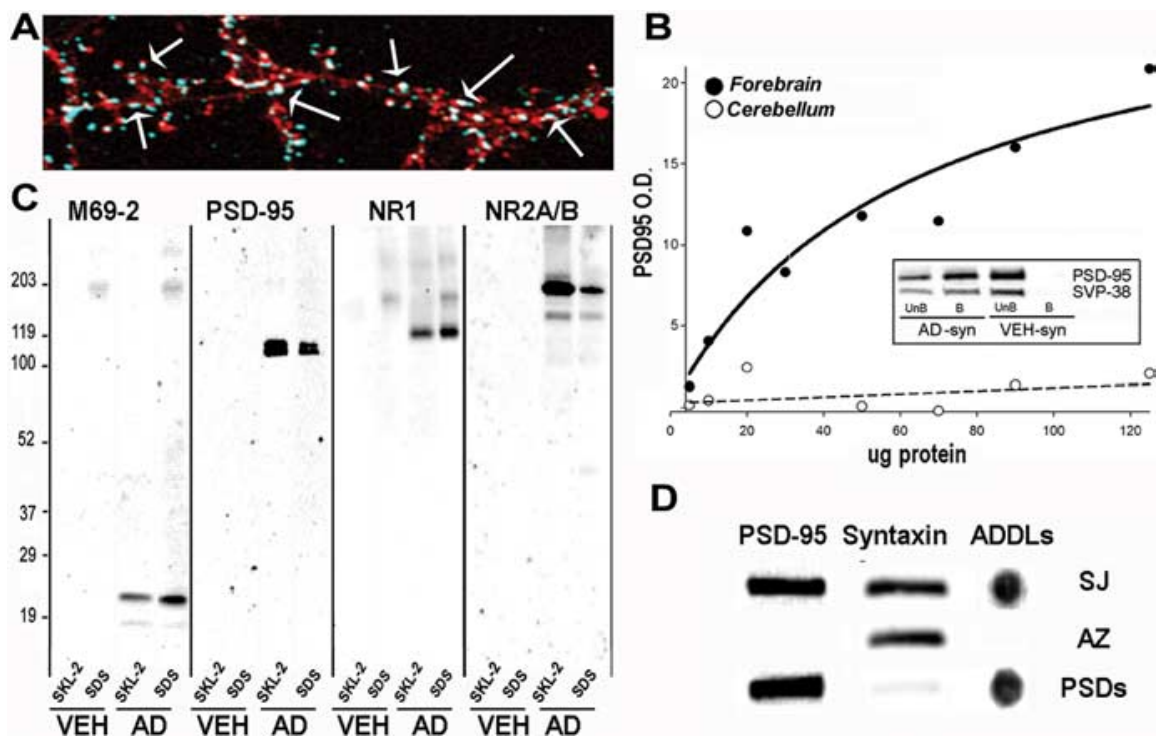

Figure 2. ADDL binding sites are postsynaptic. $\boldsymbol{A}$, High-magnification image demonstrates that ADDLs bind to dendritic spines, protrusions receiving excitatory inputs. Mature hippocampal neurons exposed to $500 \mathrm{~nm} \mathrm{ADDLs}$ for 15 min were double immunolabeled for bound ADDLs (cyan) with a monoclonal oligomer-selective antibody (NU-2) and drebrin (red), a dendritic spine marker highly expressed in dendritic spines. Merged image demonstrates a high level of colocalization (white represents the overlap, arrow) of ADDL puncta with dendritic spines. $\boldsymbol{B}$, ADDL binding is region specific. Different amounts of forebrain or cerebellar crude synaptosomes $(5-125 \mu \mathrm{g})$ were incubated with $500 \mathrm{~nm}$ ADDLs. ADDL-bound synaptosomes were immunoprecipitated using Dynabeads coupled to a polyclonal anti-oligomer-selective antibody (M71/2). The amount of immunoprecipitated material was assayed using PSD-95 antibody. Increasing PSD-95 immunoreactivity was observed from the forebrain synaptosomes, whereas cerebellar synaptosomes generated no signal. This suggests that ADDLs strongly bind to forebrain synapses but poorly to cerebellar synapses and demonstrates region specificity reminiscent of the brain area sensitivity to $A D$. Inset, $A D D L-$ treated (AD) or vehicle-treated (VEH) synaptosomes (syn) were immunoprecipitated using M71/2-coupled Dynabeads. Bound (B) and unbound $(\mathrm{UnB})$ fractions generated by the immunoprecipitation was assessed for the presence of synaptic markers (PSD-95 and SVP-38, respectively as postsynaptic and presynaptic markers). Only the "AD-syn" bound fraction showed immunoreactivity for both synaptic markers, and immunoprecipitation was specific and dependent on ADDL binding, confirming that ADDLs bind to a portion of the isolated synapses. OD, Optical Density. C, ADDL-treated synaptosomes (AD), labeled with anti-ADDLs (NU-2), incubated with Triton X-100 and DOC, and immunoprecipitated with anti-mouse lgG Dynabeads (as described in Materials and Methods) show a coisolation of ADDLs (M69-2) with postsynaptic proteins (PSD-95, NR1, and NR2A/B), all released in second Sarkosyl (SKL-2) and SDS detergent extraction. No syntaxin band was detected in these fractions (data not shown). No immunoreactive material appears in the vehicle-treated synaptosomes (VEH). Left line represents standard marker molecular weights. ADDL binding complex segregates with postsynaptic markers. $D$, Presynaptic and postsynaptic compartments of ADDL-bound synaptosomes were dissociated according to the protocol of Phillips et al. (2001). Dissociation demonstrates that ADDLs, detected by dot blot ( $0.5 \mu \mathrm{g}$ of protein) using a selective anti-oligomer antibody (NU-1), cofractionate with synaptic junctions (SJ) and PSDs, and both fractions assayed by Western blot (3 $\mu$ g of proteins) were immunopositive for PSD-95, a postsynaptic scaffolding protein. However, the active zone (AZ) fraction, which is immunoreactive for syntaxin, an integral membrane protein of the presynaptic exocytic fusion complex, did not contained ADDL-immunoreactive signal. These results confirm that ADDLs bind to excitatory synapses at postsynaptic sites.

physically coupled to NDMA-R at synaptic sites (Dalva et al., 2000). Like NMDA-R, EphB2 signaling is germane to mechanisms of synaptic plasticity (Matynia et al., 2002; Carlisle and Kennedy, 2005).

Mature hippocampal cells were treated with ADDLs for various times and immunolabeled for NR1 or NR2B subunits, or EphB2, and receptor levels were quantified using confocal microscopy. Representative images demonstrate a loss of labeled puncta along dendrites (Fig. $3 A-C$ ). Neurons with bound ADDLs after 1 and $3 \mathrm{~h}$ showed a lower number of NR1 subunits per dendritic length compared with neurons with ADDLs bound only for $2 \mathrm{~min}$ (Fig. 3A) (ANOVA over all groups, $p<0.01$ ). NMDA-R subunits were measured specifically for surface expression, using nonpermeabilized conditions and antibodies against extracellular epitopes. On average, $14 \mathrm{NR} 1$ puncta/10 $\mu \mathrm{m}$ of dendrite were detected in ADDL for 2 min or vehicle for $3 \mathrm{~h}$. In contrast, after $3 \mathrm{~h}$ of ADDL treatment, NR1 surface expression dramatically decreased $(78 \% ; p<0.005)$. Earlier times showed insignificant decreases. Over this time course, ADDLs themselves maintain their original structure (Lacor et al., 2004), although their binding pattern continues to comprise small puncta. Results obtained by immunolabeling of NR2B provided an identical conclusion. After $3 \mathrm{~h}$ ADDL treatment (Fig. 3B), there was a $70 \%$ decrease in the amount of plasma membrane-inserted NR2B subunit compared with vehicle treated at the same time point $(p<0.001)$. Measurements of fluorescence intensity per puncta also demonstrated that NR2B puncta were less bright in ADDL treated compared with vehicle treated $(p<0.001)$, suggesting a loss of receptor number inside a cluster in addition to complete loss of NR2B clusters. A surface biotinylation assay also confirmed that ADDLs significantly reduced cell surface NMDA-R but had no effect on the total amount of receptors (data not shown). Similarly, EphB2 showed a major decrease in response to ADDL exposure. EphB2 were labeled using N-terminal antibodies after 3 and $6 \mathrm{~h}$ with ADDLs, and the average number of puncta was determined (Fig. 3C). Eph family receptors in mature neurons cluster at synapses (Torres et al., 1998), and neurons treated with vehicle showed normal puncta-like EphB2 staining. Neurons incubated with ADDLs exhibited a 60\% decrease in EphB2 puncta after $6 \mathrm{~h}(p<0.001)$, again demonstrating that ADDLs deleteriously impact key synaptic receptors that participate in synaptic plasticity.

ADDLs induced changes in spine shape Our next experiments concerned the impact of ADDLs on spine shape, which, like receptor expression, is a facet of spine cell biology with major ramifications for signaling and plasticity (Harris and Kater, 1994; Carlisle and Kennedy, 2005). Both spine shape and spine receptors are F-actin sensitive, and both were previously predicted to be affected by ADDLs (Lacor et al., 2004; Klein, 2006). In these experiments, 21 DIV hippocampal neurons with mature spines were exposed to ADDLs for increasing times and then fixed and double immunostained for ADDLs and drebrin. Drebrin is an excellent spine marker that localizes to the cortical cytoskeleton of dendritic spines forming excitatory synapses (Allison et al., 2000; Aoki et al., 2005), in which it plays a physiological role in actin assembly and clustering of PSD-95 (Takahashi et al., 2003).

ADDLs can be seen to induce marked changes throughout the dendritic arbors. ADDL exposure induces an evident reduction of drebrin immunoreactivity and drebrin-labeled spines (Fig. 4) as well as dramatic changes in spine morphology and density (Fig. 5). By $6 \mathrm{~h}$, dendrites showed abnormally elongated protrusions rather than distinctive headed protrusions characteristic of mature dendritic spines such as the ones observed in the $5 \mathrm{~min}$ ADDL-treated and $24 \mathrm{~h}$ vehicle-treated groups (Fig. $5 A$ ). Even at 
$3 \mathrm{~h}$, few filopodia-like thin spines were already observed. Although the figure shows only drebrin immunoreactivity to illustrate spine changes, the neurons shown are typical of those with bound ADDLs. The change in spine appearance caused by ADDLs is especially interesting because the elongated shape resembles that of immature spines or of diseased spines found in mental retardation and prionoses (Fiala et al., 2002).

Dendrites were imaged at high magnification (Fig. 5A) to quantify changes in spine length. Initial time points showed short protrusions with spine heads close to the shaft, characteristic of mature (stubby and mushroom types) spines. Thin filopodia-like morphology developed with continued ADDL exposure time (e.g., Fig. $5 B$ shows an elongated spine with branching morphology). For quantification, spine length measurements were performed on one to two dendritic branches obtained in at least five separate images per incubation time for each experiment. The histogram summarizes the time course of ADDL-induced dendritic spine lengthening (Fig. 5C).

For additional morphometric analysis, spines were grouped into two classes based on analysis of morphology in mature hippocampal neurons (Boyer et al., 1998; Fiala et al., 2002): mature spines with spine lengths ranging from 0.2 to $2 \mu \mathrm{m}$ and abnormal protrusions longer than $2 \mu \mathrm{m}$. With ADDLs, spine populations shifted significantly toward the abnormal, longer class (Fig. 6A). More than $95 \%$ of spines exhibited a small length $(\leq 2 \mu \mathrm{m})$ in $5 \mathrm{~min}$ ADDL-treated cells, but, as early as $3 \mathrm{~h}$, a progressive shift toward longer spines $(>2$ $\mu \mathrm{m})$ was observed $(14 \% ; p<0.01)$. After $24 \mathrm{~h}$, elongated spines represented almost $40 \%$ of the spines. Use of spinophilin as an alternative spine marker to drebrin provided similar conclusions (Fig. $6 B$ ). At $1 \mathrm{~h}$, no significant spine length changes were detectable (data not shown), but, by $3 \mathrm{~h}$, $35 \%$ of the dendritic protrusions were abnormally long $(>2 \mu \mathrm{m})$ compared with only $7 \%$ in vehicle-treated neurons. Average spine length of ADDL-treated cells was $2 \pm 0.1 \mu \mathrm{m}$ compared with $1.2 \pm 0.1 \mu \mathrm{m}$ in incubation-time-matched control neurons $(p<0.005)$.

Decreased spine density and loss of drebrin caused by ADDL exposure

In $\mathrm{AD}$ and in Tg mice $\mathrm{AD}$ models, there is a significant decrease in the number of synaptic terminals (Ferrer and Gullotta, 1990; Selkoe, 2002; Scheff and Price, 2003; Coleman et al., 2004; Moolman et al.,
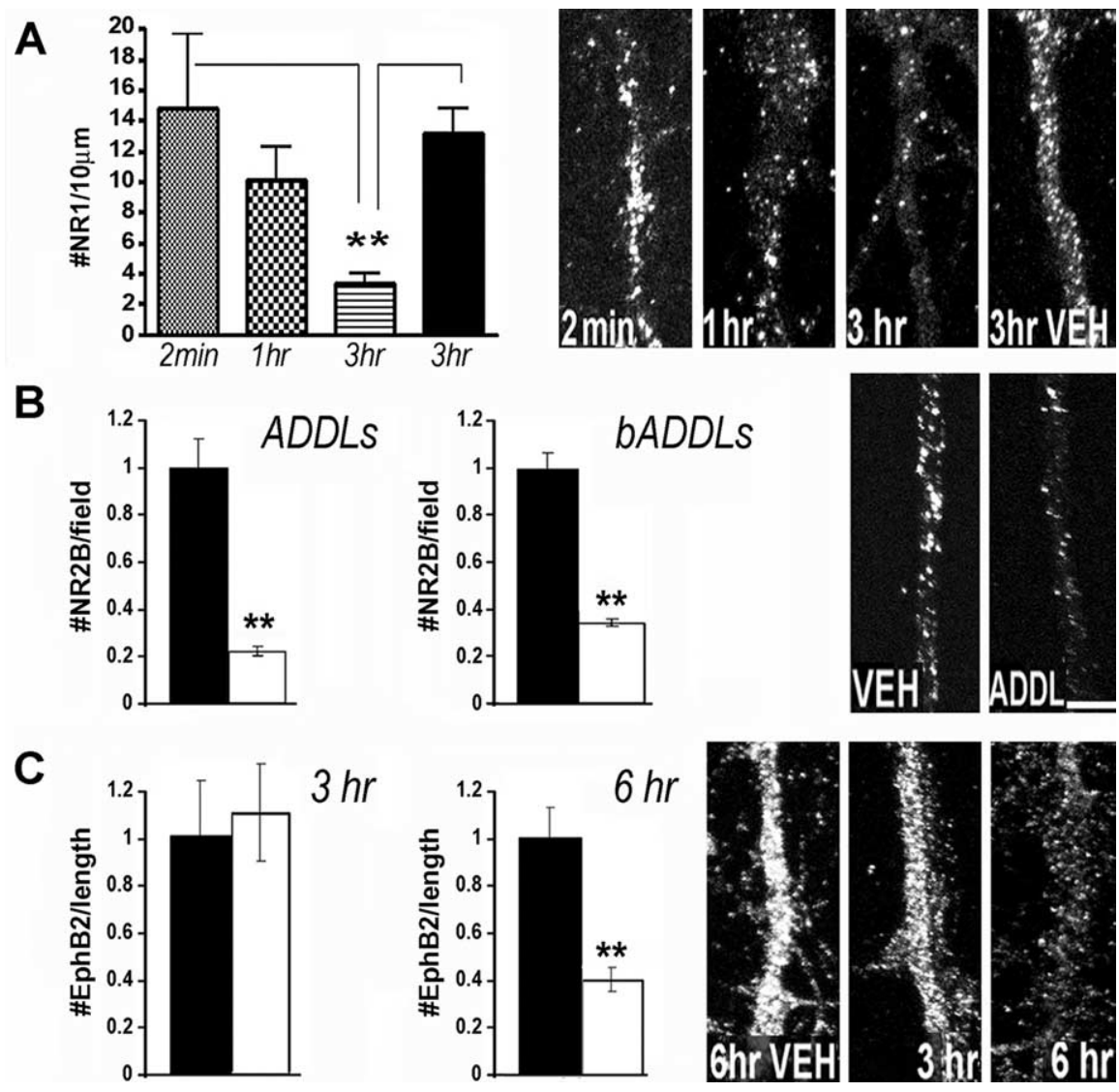

Figure 3. NMDA-R and EphB2 surface expressions are decreased after ADDL exposure. Surface expression of NR1 and NR2B subunits and EphB2 were measured using antibodies against an extracellular epitope at the $\mathrm{N}$-terminal portion of the receptor for immunolabeling under nonpermeabilizing conditions and analyzed using MetaMorph. $\boldsymbol{A}$, Quantification represents the number of NR1-labeled puncta per length of dendrite (number of NR1 puncta/10 $\mu \mathrm{m}$ dendrite). Patterned bars represent ADDL treatment at the indicated incubation time, and black bar represents vehicle treatment at $3 \mathrm{~h}$. Density of NR1 tends to decrease after AD $1 \mathrm{~h}$ $(10.1 \pm 2.2 ; n=11 ; \mathrm{NS})$ and highly decrease after $\mathrm{AD} 3 \mathrm{~h}(3.3 \pm 0.7 ; n=11 ; p=0.002)$ compared with controls represented by $A D 2 \min (14.3 \pm 4.8 ; n=9)$ and VEH $3 \mathrm{~h}(13.1 \pm 1.4 ; n=9)$. The follwoing dendritic lengths were measured over the different groups of treatment: AD 2 min, $383 \pm 36 \mu \mathrm{m} ; A D 1 \mathrm{~h}, 325 \pm 25 \mu \mathrm{m} ; \mathrm{AD} 3 \mathrm{~h}, 348 \pm 32 \mu \mathrm{m} ; \mathrm{VEH} 3 \mathrm{~h}, 252 \pm 29 \mu \mathrm{m}$. $\boldsymbol{B}$, A significant decrease in the number of NR2B puncta per field was observed after AD $3 \mathrm{~h}(p<0.001 ; n=10)$. The average number of puncta for treated neurons was normalized against the mean value of vehicle-treated ones. A similar decrease was observed after $1 \mathrm{~h}$ biotinylated ADDL (bADDLs) treatment. Black bar represents vehicle, and white bar represents ADDL or bADDL. C, A significant decrease in the number of EphB2-labeled puncta per length of dendrite was observed after AD $6 \mathrm{~h}(p=0.0005$; $n=15)$, although the difference at $3 \mathrm{~h}$ was not significant ( $p=0.55)$. The average number of puncta per length of dendrite for ADDL treated was normalized against the mean value of vehicle treated. Black bar represents vehicle, and white bar represents ADDL. Right panel shows representative images of dendritic branches labeled with NR1 $(\boldsymbol{A}), \operatorname{NR2B}(\boldsymbol{B})$, and EphB2 $(\boldsymbol{C})$ antibodies at indicated time points of treatment. Scale bar, $8 \mu \mathrm{m} .{ }^{* *} p=0.0005$.
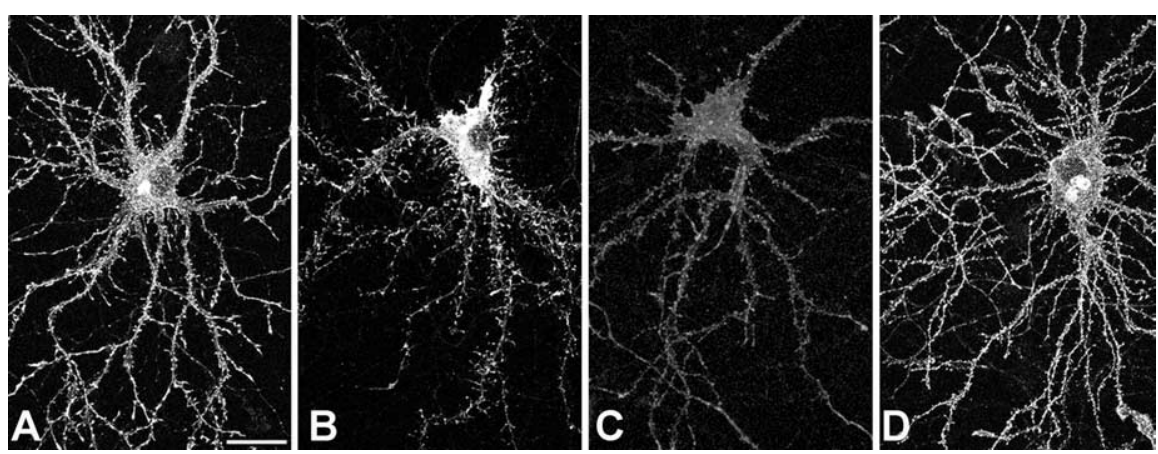

Figure 4. Time-dependent changes in drebrin distribution attributable to ADDLs. Cells treated with ADDL for $5 \mathrm{~min}(\boldsymbol{A}), 6 \mathrm{~h}(\boldsymbol{B})$, and $24 \mathrm{~h}(\boldsymbol{C})$ and vehicle for $24 \mathrm{~h}(\boldsymbol{D})$ and immunolabeled for drebrin, an actin binding protein enriched in dendritic spines, were imaged by confocal laser-scanning microscope. A reduction in drebrin labeling is particularly pronounced at $24 \mathrm{~h}$ after ADDL treatment. Scale bar, $30 \mu \mathrm{m}$. 


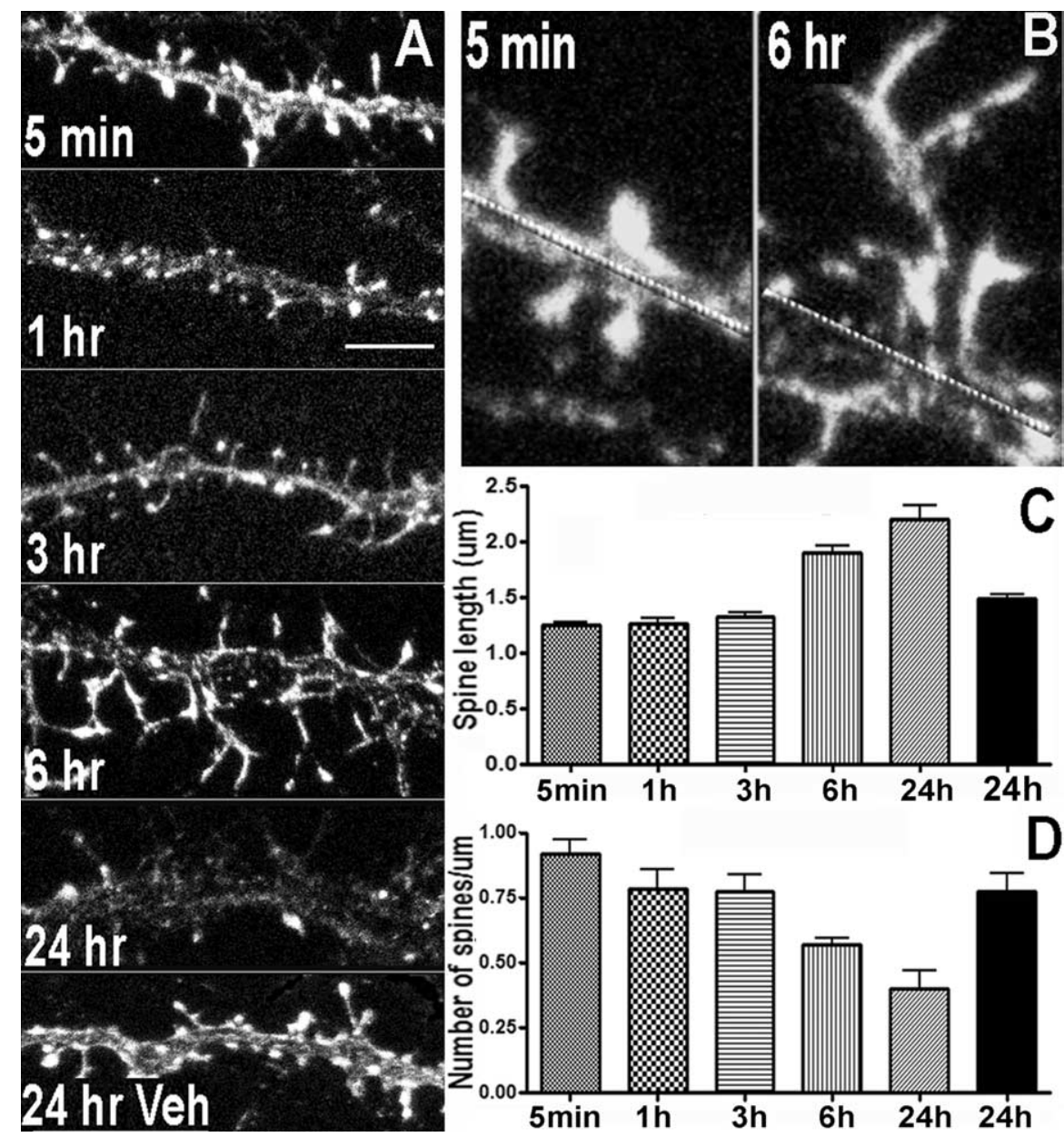

Figure 5. $A D D L$-induced aberrations in dendritic spine morphology and density. $\boldsymbol{A}$, Confocal microscopy images representative of individual dendritic branches decorated with spiny protrusions immunolabeled for drebrin after ADDL or vehicle (Veh) treatment. Longer and more irregularly shaped spines appear after as early as $3 \mathrm{~h}$ treatment and are more pronounced after $6 \mathrm{~h}$. Also note the fewer amount of dendritic spines present after $24 \mathrm{~h} \mathrm{ADDL}$. Scale bar, $5 \mu \mathrm{m}$. B, Illustration of zoomed dendritic branches harboring "spines" demonstrates the dramatic lengthening of dendritic protrusions after $6 \mathrm{~h}$ of ADDL treatment. The line marks the dendritic shaft. C, D, Histograms represent average length and density of drebrin-labeled dendritic spines after ADDL (patterned bars) or vehicle (black bars) incubation at various times. Spine measurements were obtained from a minimum of five separate images per group of treatment and from two independent experiments. Spine lengths were as follows (in $\mu \mathrm{m}$ ): $A D$ 5 min, $1.1 \pm 0.02, n=365$ spines; Veh $24 h, 1.2 \pm 0.03, n=315$, NS vs AD 5 min; AD 1 h, $1.3 \pm 0.05, n=219, p>0.05$ vs controls; AD 3 h, $1.3 \pm 0.04, n=233, p<0.01 ; A D 6 h, 1.8 \pm 0.06, n=322, p<0.001 ; A D 24 h, 2.0 \pm 0.10, n=110, p<$ 0.001 . Spine densities per $10 \mu \mathrm{m}$ of dendrite were as follows: $A D 5 \mathrm{~min}, 9.2 \pm 0.6, n=18$ dendritic branches; $A D 1 \mathrm{~h}, 7.9 \pm 0.7$ $n=10, p>0.05 ; \operatorname{AD} 3 \mathrm{~h}, 7.8 \pm 0.6, n=9, p<0.01 ; \operatorname{AD} 6 \mathrm{~h}, 5.7 \pm 0.3, n=18, p<0.0001 ; \operatorname{AD} 24 \mathrm{~h}, 4.0 \pm 0.7, n=10, p<$ 0.001 ; Veh $24 h, 7.7 \pm 0.7, n=16, p>0.05$.

2004; Spires et al., 2005; Counts et al., 2006; Jacobsen et al., 2006), which is considered the best correlate of dementia (DeKosky and Scheff, 1990; Terry et al., 1991; Sze et al., 1997). Tg mice also exhibit decreased drebrin (Calon et al., 2004), consistent with loss of spines. The molecular basis for this loss of terminals is unknown. Analysis of the current data establishes that terminal loss could be instigated at the molecular level by ADDLs.

Neurons with bound ADDLs by $24 \mathrm{~h}$ showed a striking change in density of drebrin-labeled spines (Fig. $5 A, D$ ). At $3 \mathrm{~h}$, spine density was not significantly changed, but, by $6 \mathrm{~h}$, a decrease of $33 \%$ was observed $(p<0.001)$. By $24 \mathrm{~h}$, the decrease in spines was $50 \%(p<0.001)$, and, at this time, there also was an overall decrease in drebrin immunofluorescence. In contrast, neurons exposed for 24 h to vehicle displayed normal dendritic drebrin, spine density, and shape, identical to that observed with a $5 \mathrm{~min}$ ADDL incubation; neurons not targeted by ADDLs also were identical to neurons exposed only to vehicle. Throughout the experiment, cultures showed only ADDL-positive punctate binding on cells, never exhibiting the large deposits evident in cultures incubated with protofibrillar or fibrillar $\mathrm{A} \beta$ described by Hartley et al. (1999). The data provide direct cell biological evidence for the hypothesis that the mechanism of spine degeneration in $\mathrm{AD}$ is instigated at the molecular level by the binding of $\mathrm{AD}$ DLs to synaptic terminals.

\section{Drebrin loss is attributable to A $\boldsymbol{\beta}$ oligomers}

We reported previously that synaptic ligands found in preparations of soluble $\mathrm{A} \beta$ oligomers pass readily through $100 \mathrm{kDa}$ but not $10 \mathrm{kDa}$ cutoff filters (Lacor et al., 2004). Extending this analysis, we observed that $50 \mathrm{kDa}$ filters retained essentially all synaptic binding activity (Fig. 7A, $50 \mathrm{k}-\mathrm{R})$, although approximately half of the protein passed into the filtrate (Fig. $7 B)$. The synaptic ligands thus were composed of oligomers of size comprised between 50 and $100 \mathrm{kDa}$. This finding parallels previous fractionations of binding activity by size exclusion chromatography-HPLC (Chromy et al., 2003; Lacor et al., 2004). As expected, no ligand activity passed through $10 \mathrm{kDa}$ filters (Fig. 7A, $10 \mathrm{k}-\mathrm{F})$. In these experiments, binding was assessed using the 6 E10 monoclonal antibody, which recognizes monomers as well as higher-order species. Interestingly, the $10 \mathrm{kDa}$ cutoff filtrates had very little protein, $<1 \%$ of the total (Fig. $7 B$ ). ADDLs prepared by our protocol thus contained almost no $\mathrm{A} \beta$ monomers; in fact, the monomeric band in the $10 \mathrm{kDa}$ filtrate was visible by silver stain only by loading 26 times more filtrate than retentate (Fig. 7B). As a control, the ability of monomer to pass readily through the $10 \mathrm{kDa}$ filter was confirmed by use of $\mathrm{A} \beta_{1-40}$ (Fig. $7 B$ ), which is known to remain monomeric under the conditions used here. We also noted that oligomers in 10 and $50 \mathrm{kDa}$ retentates showed prominent small species after SDSPAGE (monomers, trimers, and tetramers), consistent with denaturation of larger oligomers as originally reported (Lambert et al., 1998). Ligands in the retentates of 10 and $50 \mathrm{kDa}$ filters provided characteristic punctate binding on dendritic processes, and, most significantly, their binding led to severe drebrin loss (Fig. 8). In contrast, $\mathrm{A} \beta_{1-40}$ monomers, as well as species that might have formed during the $24 \mathrm{~h}$ incubation with cells, did not affect drebrin expression (Fig. 8). Overall results demonstrate that soluble $\mathrm{A} \beta$ species that bind to dendritic processes and induce synapse loss comprise $\mathrm{A} \beta_{1-42}$ oligomers between 50 and 100 $\mathrm{kDa}$. With respect to size, these synaptotoxic oligomeric ligands are consistent with the prominent 12 -mers found in $\mathrm{AD}$ brain (Gong et al., 2003) and with a $56 \mathrm{kDa} \mathrm{A} \beta$ species reported for a $\mathrm{Tg}$ AD mouse model (Lesne et al., 2006). 

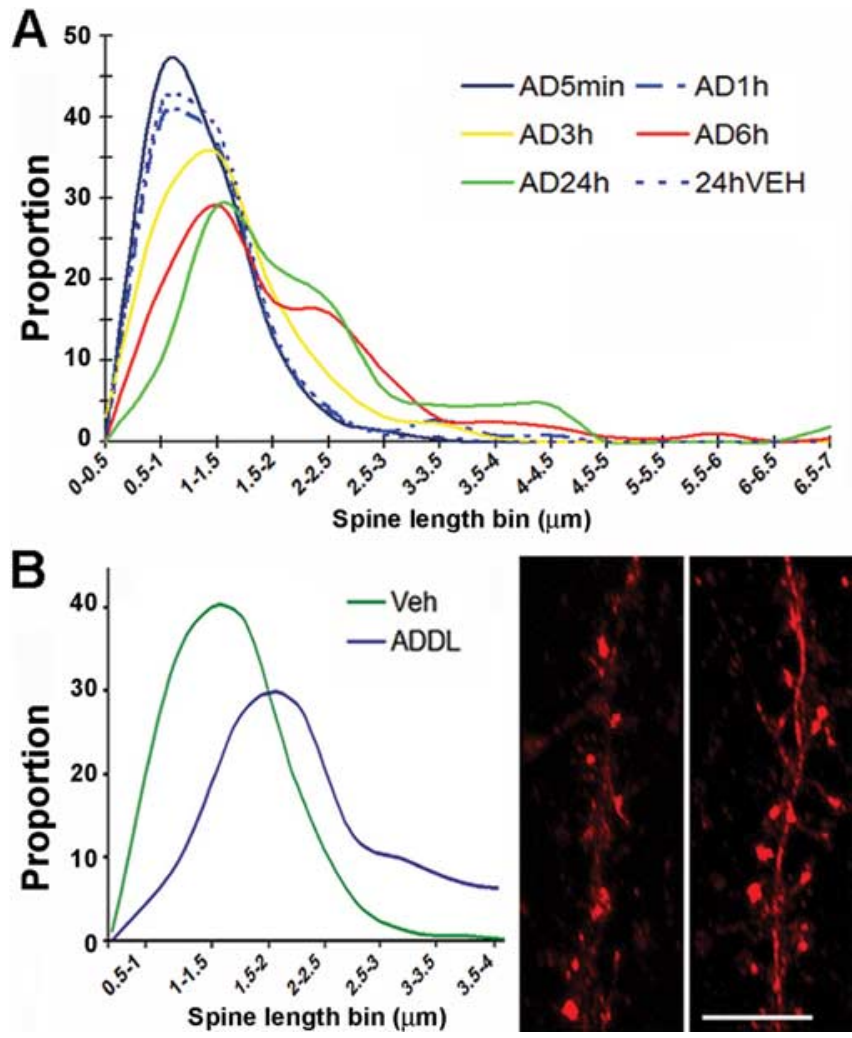

Figure 6. Shift in dendritic spine length monitored by drebrin $(\boldsymbol{A})$ and spinophilin $(\boldsymbol{B}) . \boldsymbol{A}$, Spine length distribution in hippocampal neurons incubated with $500 \mathrm{~nm}$ ADDLs (AD) or vehicle (VEH) at different times. The curves represent the observed shift in dendritic spine length after ADDL treatment. Although most of the spines have a length of $0.5-2 \mu \mathrm{m}$ in $A D 5 \mathrm{~min}, A D 1 \mathrm{~h}$, and VEH $24 \mathrm{~h}$, occurrence of longer spines is significantly increased in AD $6 \mathrm{~h}$ and $A D 24 \mathrm{~h} . \boldsymbol{B}$, Labeling of spinophilin, another cytoplasmic scaffolding protein highly concentrated in spines, showed that dendritic spine length was increased after $A D 3 \mathrm{~h}$ (average spine length was $1.99 \pm 0.1 \mu \mathrm{m})$ compared with time-matched vehicle $(1.23 \pm 0.04 \mu \mathrm{m})(p<0.005,10$ dendritic branches from different neurons imaged, $\sim 200$ spine length measurements per group of treatment). High-magnification images of spinophilin IF show dendritic branches harboring spines under vehicle (left) or ADDL (right) treatment. Scale bar, $8 \mu \mathrm{m}$.

\section{Prevention of drebrin loss by memantine}

Although evidence from model membranes (Lin et al., 2001) suggests that ADDLs ostensibly might exert synaptotoxicity by creating annular pores within plasma membranes, the specificity of binding to particular synaptic spines has been suggested to support a receptor-mediated mechanism in situ (Lacor et al., 2004; Klein et al., 2007). Because the Alzheimer's drug Namenda (memantine) is thought to function therapeutically as an openchannel blocker of NMDA receptors (Lipton, 2006) and NMDA receptors codistribute in hippocampal cultures with ADDLs, we tested whether memantine might exhibit efficacy in blocking ADDL-induced drebrin loss.

Relative drebrin immunofluorescence was expressed as intensity per unit neuronal area, which was measured at high magnification and typically contained one or two ADDL-positive neurons per field (Fig. 9A). As expected, neurons pretreated with water (solvent for memantine) for $30 \mathrm{~min}$ followed by $24 \mathrm{~h} \mathrm{ADDL}$ treatment exhibited $\sim 40 \%$ loss of drebrin expression (Fig. 9 C). However, neurons pretreated with memantine followed by ADDL treatment failed to exhibit such decreases in drebrin. Benefit from memantine occurred without blocking of ADDL binding (Fig. 9B). Confirmation that ADDL attachment was identical with or without memantine has been obtained by quantitative image analysis of acute binding (30 min memantine followed by
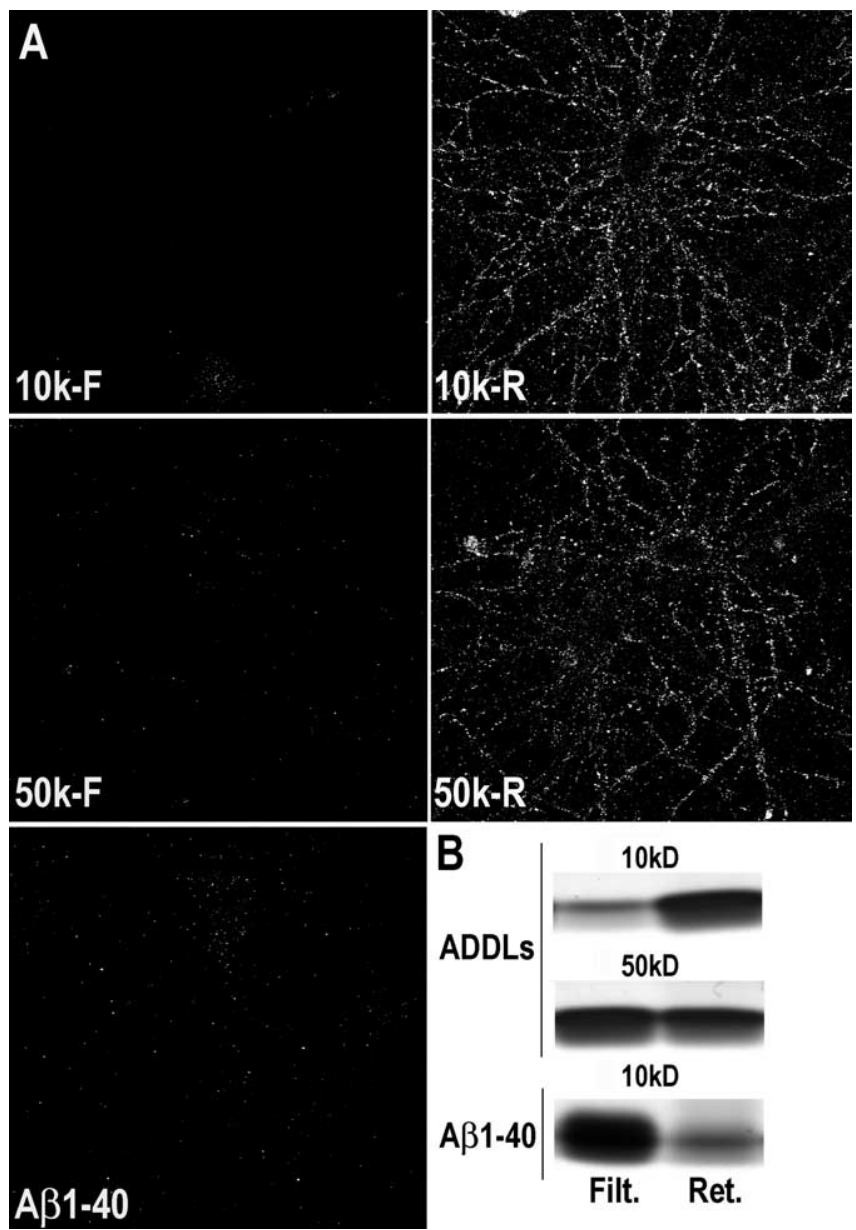

Figure 7. ADDLs species $>50 \mathrm{kDa}$ are synaptic ligands. $\boldsymbol{A}$, Immunolabeling of $A \beta$-bound species with $6 \mathrm{E} 10$, a monoclonal antibody that recognizes monomeric form of $A \beta$ as well as higher $A \beta$ species, revealed that only $A D D L$ species above $50 \mathrm{kDa}$, but not monomer, bind in a hot spot pattern on dendritic process of hippocampal cells. Cells were incubated for $15 \mathrm{~min}$ with either filtrate or retentate from $10 \mathrm{kDa}$ cutoff filter (10k-F and $10 \mathrm{k}-\mathrm{R}$, respectively), filtrate or retentate from $50 \mathrm{kDa}$ cutoff filter ( $50 \mathrm{k}-\mathrm{F}$ and $50 \mathrm{k}-\mathrm{R}$, respectively), or $A \beta_{1-40}$. $\boldsymbol{B}$, Ultrafiltration shows that ADDL preparations contain almost no monomers. ADDLs were separated by 10 and $50 \mathrm{kDa}$ cutoff filters into filtrate (Filt.) and retentate (Ret.) fractions and then analyzed by SDS-PAGE and silver stain. The bands illustrated are those migrating to the monomer position, which is the predominant silver-stained species after oligomer disassociation in SDS as described previously (Lambert et al., 1998). Material in the $10 \mathrm{kDa}$ filtrate is negligible compared with the retentate fraction; to obtain the faint signal shown, the loading volume used for filtrate was 26 times greater than for retentate. For the $50 \mathrm{kDa}$ cutoff fractions, equal loading volumes were used. Data show that essentially all material in ADDL preparations was larger than monomer, and approximately half was larger than $50 \mathrm{kDa}$. $A$ control $\left(A \beta_{1-40}\right)$ shows that monomers, when present, pass readily through $10 \mathrm{kDa}$ cutoff filters.

60 min ADDL exposure) (F. De Felice and W. L. Klein, unpublished observation). Lack of inhibition does not rule out, however, the possibility of ADDL binding to some domains within or nearby NMDA receptors. Results obtained by imaging were confirmed by Western blot analysis (Fig. 9D). Drebrin loss was not attributable to neuronal loss because levels of neuron-specific enolase were comparable between the treatment groups (data not shown). These results show that ADDL synaptotoxicity is dependent on memantine-sensitive receptors and suggest that cognitive benefits conferred to $\mathrm{AD}$ patients by memantine derive from protection against the deleterious synaptic impact of ADDLs.

\section{Discussion}

Synapse loss is the most robust correlate of AD-associated cognitive deficits (DeKosky and Scheff, 1990; Terry et al., 1991; Sze et 

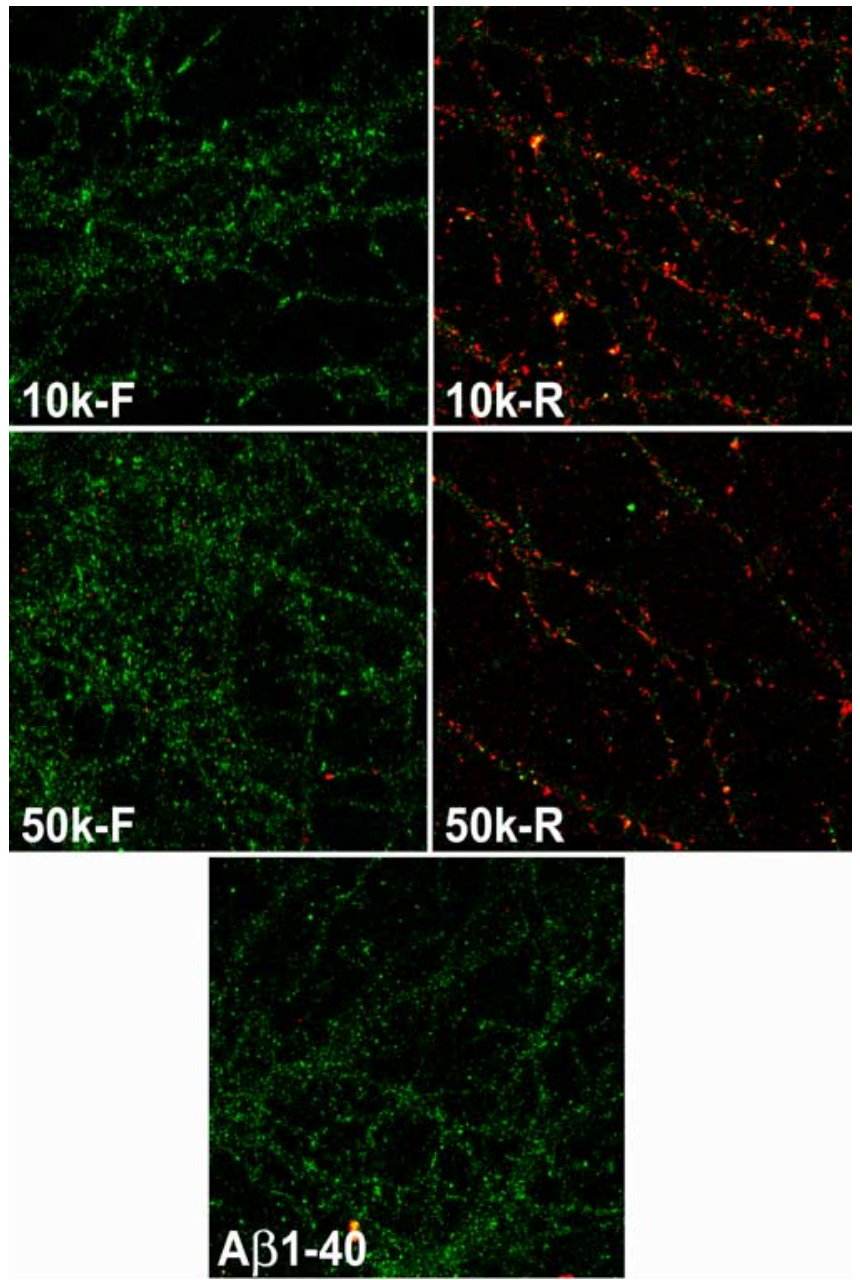

Figure 8. Drebrin loss is attributable to $A \beta$ oligomers. Cells double labeled for drebrin (green) and ADDLs (M94, red) show major drebrin loss when ADDL-binding species are bound to the dendritic processes. Cells were treated for $24 \mathrm{~h}$ with either filtrate or retentate of 10 or 50 $\mathrm{kDa}$ cutoff filters (10k-F, 10k-R, 50k-F, and 50k-R, respectively). Representative images show high drebrin in the absence of ADDL binding (10k-F, 50k-F) but very low drebrin labeling in dendritic processes in the presence of $A D D L$ labeling $(10 \mathrm{k}-\mathrm{R}, 50 \mathrm{k}-\mathrm{R})$. Note that $A \beta_{1-40} \mathrm{prepa}-$ rations showed neither binding nor drebrin loss.

al., 1997; Masliah et al., 2001; Selkoe, 2002; Coleman et al., 2004), but the mechanism responsible for loss of connections is not established. Originally, synapse loss was thought to depend on the toxicity of insoluble amyloid fibrils. More recently, it has been hypothesized that synapse dysfunction and degeneration are the early consequences of soluble A $\beta$ oligomers (Klein et al., 2001; Selkoe, 2002; Walsh and Selkoe, 2004; Klein, 2006; Standridge, 2006), which are potent CNS neurotoxins (Lambert et al., 1998) that accumulate in AD brain (Gong et al., 2003) and CSF (Georganopoulou et al., 2005). Current findings provide direct cell biological evidence for this hypothesis, establishing that ADDLs alter spine composition, morphology, and density.

Changes in spine properties induced by ADDLs extend previous findings that ADDLs rapidly block LTP (Lambert et al., 1998; Wang et al., 2002) by binding directly to dendritic spines (Lacor et al., 2004). The premise that ADDLs occur extracellularly was verified recently in nanotechnology-based assays (Georganopoulou et al., 2005; Haes et al., 2005), which established diseasedependent accumulation of ADDLs in CSF. In AD brain, ADDL immunoreactivity distributes perineuronally with no intracellular staining, as also seen in cell biological observations (Lacor et al., 2004; Lambert et al., 2007). Although ADDLs accumulate intraneuronally in some Tg mice, these models show a dynamic partitioning between intracellular and extracellular oligomers (Oddo et al., 2006a), consistent with the ability of stereotaxic injection of oligomer-specific antibodies to reverse transgenedependent tau hyperphosphorylation (Oddo et al., 2006b). In Tg mice, onset of memory failure coincides with the accumulation of a 12-mer (Lesne et al., 2006), a $54 \mathrm{kDa}$ species shown previously to accumulate in AD brain and in vitro (Klein, 2002; Chromy et al., 2003; Gong et al., 2003). In our current studies, the synaptotoxic $\mathrm{ADDL}$ species were $>50 \mathrm{kDa}$. It has been reported that trimers that form in cell-conditioned culture medium also show neurological effects (Townsend et al., 2006).

Because ADDLs block onset of LTP and reversal of LTD and they disrupt NMDA-receptor-mediated CREB phosphorylation (Tong et al., 2001), it has been predicted that surface glutamate receptor levels would be altered by ADDL exposure (Gong et al., 2003). Supporting this possibility, ADDLs ectopically induce Arc (Lacor et al., 2004), a spine cytoskeletal protein that influences glutamate receptor trafficking (Mokin et al., 2006). Current results confirm that ADDLs cause a major loss of surface NMDARs. Loss of these receptors has been shown in AD brain (Sze et al., 2001; Mishizen-Eberz et al., 2004) and Tg2576 mice (Snyder et al., 2005) and correlates with synaptic alterations and cognitive deficits (Terry et al., 1991; Sze et al., 1997; Counts et al., 2006). The large decrease in receptor expression seen here occurs before any major change in spine density, consistent with synaptic plasticity being compromised before degeneration.

In addition to affecting NMDA-Rs, ADDLs were observed to induce a major decrease in EphB2. These two synaptic receptors physically interact via their extracellular domains (Dalva et al., 2000) and are functionally related to plasticity. NMDA-Rs play a central role in the induction of LTP (Morris and Davis, 1994). and EphB2 exerts control over NMDA-dependent LTP (Matynia et al., 2002). Interestingly, both receptors also influence dendritic spine morphology and maintenance (Carlisle and Kennedy, 2005).

We reported previously that neuronal binding of synthetic and Alzheimer's brain-derived ADDLs is highly specific (Lacor et al., 2004), despite the potential of $A \beta$ for generically inserting into lipid bilayers (Lin et al., 2001). The current data verify that extracellular ADDLs act as pathogenic gain-of-function ligands that target synaptic spines, shown by the codistribution of ADDLs with the spine marker drebrin. Specific binding requires adventitious attachment of ADDLs to particular membrane proteins, because binding sites are eliminated by mild proteolysis of cell surfaces (Lambert et al., 1998) or synaptosomes (A. Sanz Clemente, P. T. Velasco, and W. L. Klein, unpublished observation). As with other synaptic proteins, ADDL binding sites are presumably enriched at synapses by mechanisms involving postsynaptic densities (Sheng, 2001) and possibly lipid rafts (Hering et al., 2003). Consistent with this possibility, development of clustered binding sites in hippocampal cultures shows late onset, with puncta becoming abundant during the third week in conjunction with molecular maturation of postsynaptic domains (P. N. Lacor, unpublished observation). Association of ADDL binding sites with synaptic scaffolding is further supported by fractionation experiments, in which extraction of ADDL-labeled synaptosomes with mild detergents yielded complexes containing ADDLs and PSD proteins (Fig. 2). The ADDL binding site itself is not yet known, but it is likely that ADDLs bind near or to NMDA receptors, which are implicated in ADDL-mediated spine dysfunction and cofractionate with ADDLs released from synaptosomes. Recent 
work has shown, moreover, that preincubation of neurons with antibodies against extracellular domains of NMDA receptors greatly reduces ADDL binding and ADDL-induced reactive oxygen species formation (Klein et al., 2007). Although current findings show that the NMDA receptor antagonist memantine inhibits ADDL-induced drebrin loss without preventing ADDL binding, this pattern is consistent with the known action of memantine as an uncompetitive openchannel blocker.

Because of ADDL impact on Arc, a spine protein that associates with F-actin, it also has been predicted that spine shape would be altered by ADDL exposure (Lacor et al., 2004). As predicted, ADDLs were found to produce marked changes in spine shape, generating elongated filopodia-like dendritic protrusions typically associated with deafferentation, prionoses, and various mental retardation disorders (Fiala et al., 2002). The known relationship between abnormal spine morphology and cognitive dysfunction implies that ADDLinduced spine pathology could be a factor in the loss of functional connectivity in AD. Overall, ADDL-induced responses are consistent with anomalous activation of NMDA receptors (Lacor et al., 2004; Klein et al., 2007), and abnormal spine shape hypothetically could involve NMDA receptor stimulation of extracellular signalregulated kinase (ERK) activity. ERK is involved in the structural remodeling of excitatory synapses (Alonso et al., 2004), possibly by affecting the ability of spinophilin to bundle F-actin (Futter et al., 2005) or by altering the expression of Arc (Ying et al., 2002). Remodeling of actin filaments is a key determinant of spine shape (Matus, 2000) and plays a role in LTP (Okamoto et al., 2004; Zito et al., 2004). F-actin organization also is affected by drebrin, another cytoskeleton protein concentrated in dendritic spines that normally is regulated by NMDA receptors (Sekino et al., 2006). In response to ADDLs, drebrin undergoes major redistribution, being nearly eliminated from spines and dendrites after $24 \mathrm{~h}$. Consistent with these findings, drebrin is decreased in AD patients (Hatanpaa et al., 1999; Shim and Lubec, 2002) and Tg mouse AD models (Calon et al., 2004), reinforcing the idea that ADDL-induced spine dysfunction contributes to cognitive failure in $\mathrm{AD}$. Although ERK stimulation by low levels of soluble forms of $A \beta$ could be germane to abnormalities induced in spine shape, at higher levels of $\mathrm{A} \beta$, it appears to mediate neurotoxicity (Chong et al., 2006), possibly through glial activation (Combs et al., 1999). At this time, however, given that multiple signaling pathways are relevant to spine morphology (Ethell and Pasquale, 2005), the exact mechanism affected by ADDLs remains uncertain.

The current experiments have focused on the shape of den-
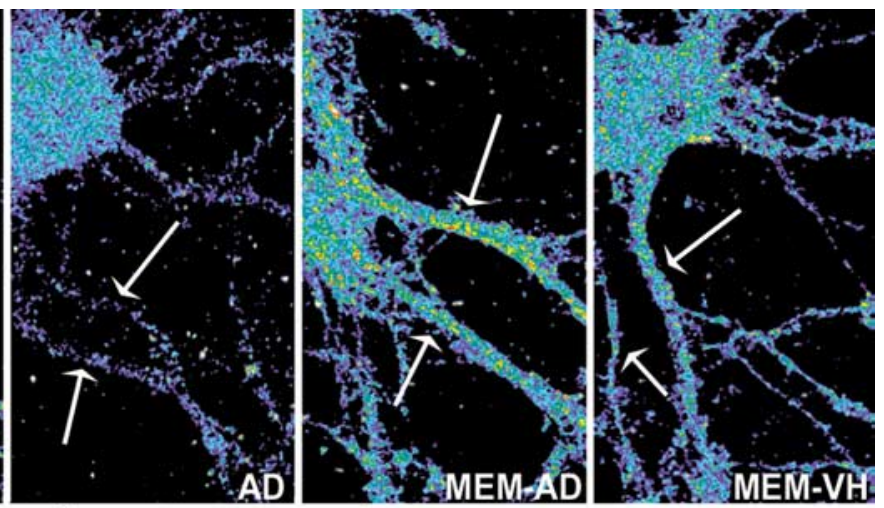

C
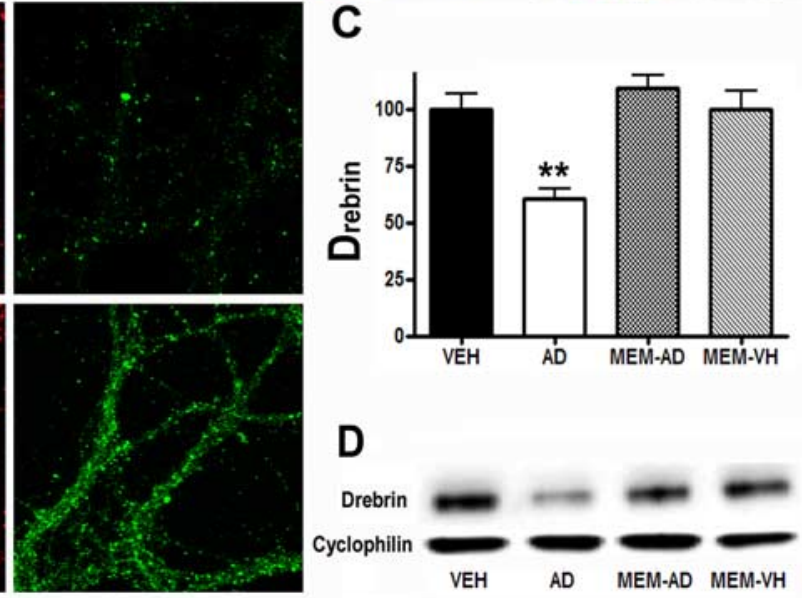

Drebrin

Figure 9. Memantine prevents ADDL-induced dendritic drebrin loss. $\boldsymbol{A}$, Confocal microscopy images of drebrin immunofluorescent labeling in 21 DIV cultured rat hippocampal neurons. Grayscale intensities ranging from black to white were converted in a pseudocolor lookup table with increasing values of gray intensity. Black (0) is representing the darkest intensity, and white (255) indicated by the arrows, dendrites of neurons treated with ADDLs for $24 \mathrm{~h}(\mathrm{AD})$ exhibit decreased drebrin immunofluorescence co drebrin hot spots (yellow-red) present in the neurons treated with F-12 vehicle for $24 \mathrm{~h}$ ( of treatment, demonstrating that memantine prevents ADDL-induced drebrin loss but does not alter ADDLs binding to synapses. C, Bar graph illustrating quantification of drebrin immunofluorescence integrated density from confocal image sets as shown in $\boldsymbol{A}$. Values are normalized to vehicle-treated cells (VEH) for $24 \mathrm{~h}$. Difference between VEH ( $n=25)$ versus $\mathrm{AD}(n=31)$ and AD versus same manner as neurons imaged in $\boldsymbol{A}$. Blots were probed with anti-drebrin, and antibody against cyclophilin was used as control of protein loaded in each lane.

dritic spines rather than presynaptic terminals because ADDL binding appears primarily postsynaptic. We have noted, however, that presynaptic terminals (labeled for synaptophysin) have larger sizes after $6 \mathrm{~h}$ ADDL treatment, without changes in the total number of synaptophysin puncta (Klein et al., 2007). There are similar indications of enlarged boutons in early $\mathrm{AD}$ (Mukaetova-Ladinska et al., 2000; Scheff and Price, 2003). This pathological enlargement could constitute a homeostatic compensation to preserve synaptic function.

Morphological reorganization initiated by ADDLs ultimately culminates in a loss of dendritic spines. Pathological loss of spines and their associated molecules is well documented for AD brain (Scheibel, 1983; Shim and Lubec, 2002; Scheff and Price, 2003) and Tg mouse AD models (Lanz et al., 2003; Calon et al., 2004; Moolman et al., 2004; Spires et al., 2005; Jacobsen et al., 2006). 
The identity of molecules that cause spine deterioration has not been established, but, because both $\mathrm{AD}$ subjects (Gong et al., 2003; Lacor et al., 2004) and Tg mice accumulate substantial levels of ADDLs (Chang et al., 2003; Oddo et al., 2006b; Ohno et al., 2006), it has been proposed that these synaptic ligands are the responsible toxins (Lacor et al., 2004; Klein, 2006). The current data substantiate this possibility, providing direct evidence that ADDL attachment to synapses induces spine loss. Protection against ADDL pathological effects on synapses is afforded by memantine (Namenda), currently prescribed as a means of temporarily preserving cognitive capacity in $\mathrm{AD}$ patients. The anti-ADDL activity of memantine may provide a neuropharmacological mechanism germane to understanding and possibly improving the therapeutic benefits of the drugs.

Findings here show that ADDLs rapidly stimulate loss of critical spine proteins, concomitantly producing aberrant spine morphology and eventually causing a significant reduction in spine abundance. Results thus provide a cell biological mechanism to account for synaptic degeneration in AD. This new impact on synapses complements previous studies showing that ADDLs selectively compromise synaptic plasticity (Lambert et al., 1998; Klein et al., 2001; Wang et al., 2002) and nerve cell viability (Lambert et al., 1998). More recently, other investigations have established that ADDLs also stimulate generation of reactive oxygen species and $\mathrm{AD}$-type tau hyperphosphorylation (Klein et al., 2007). Together, these findings indicate that the neuronal impact of ADDLs could provide a unifying pathogenic mechanism for $\mathrm{AD}$, explaining why early $\mathrm{AD}$ is specific for memory loss and accounting for the major facets of AD neuropathology. Because the pathogenic consequences of ADDLs derive from a ligand-like attachment to specific synaptic proteins (Gong et al., 2003; Lacor et al., 2004), it will be important in the future to identify these toxin receptors and determine their role in inducing the cellular substrates of dementia. Novel therapeutic strategies aimed at blocking ADDL attachment to synapses or contravening its consequences should ultimately be successful at preserving cognitive function by preventing the critical pathological loss of synaptic connectivity.

\section{References}

Allison DW, Chervin AS, Gelfand VI, Craig AM (2000) Postsynaptic scaffolds of excitatory and inhibitory synapses in hippocampal neurons: maintenance of core components independent of actin filaments and microtubules. J Neurosci 20:4545-4554.

Alonso M, Medina JH, Pozzo-Miller L (2004) ERK1/2 activation is necessary for BDNF to increase dendritic spine density in hippocampal CA1 pyramidal neurons. Learn Mem 11:172-178.

Aoki C, Sekino Y, Hanamura K, Fujisawa S, Mahadomrongkul V, Ren Y, Shirao T (2005) Drebrin A is a postsynaptic protein that localizes in vivo to the submembranous surface of dendritic sites forming excitatory synapses. J Comp Neurol 483:383-402.

Boyer C, Schikorski T, Stevens CF (1998) Comparison of hippocampal dendritic spines in culture and in brain. J Neurosci 18:5294-5300.

Buttini M, Masliah E, Barbour R, Grajeda H, Motter R, Johnson-Wood K, Khan K, Seubert P, Freedman S, Schenk D, Games D (2005) Betaamyloid immunotherapy prevents synaptic degeneration in a mouse model of Alzheimer's disease. J Neurosci 25:9096-9101.

Calon F, Lim GP, Yang F, Morihara T, Teter B, Ubeda O, Rostaing P, Triller A, Salem Jr N, Ashe KH, Frautschy SA, Cole GM (2004) Docosahexaenoic acid protects from dendritic pathology in an Alzheimer's disease mouse model. Neuron 43:633-645.

Carlisle HJ, Kennedy MB (2005) Spine architecture and synaptic plasticity. Trends Neurosci 28:182-187.

Chang L, Bakhos L, Wang Z, Venton DL, Klein WL (2003) Femtomole immunodetection of synthetic and endogenous amyloid-beta oligomers and its application to Alzheimer's disease drug candidate screening. J Mol Neurosci 20:305-313.
Chong YH, Shin YJ, Lee EO, Kayed R, Glabe CG, Tenner AJ (2006) ERK1/2 activation mediates Abeta oligomer-induced neurotoxicity via caspase-3 activation and tau cleavage in rat organotypic hippocampal slice cultures. J Biol Chem 281:20315-20325.

Chromy BA, Nowak RJ, Lambert MP, Viola KL, Chang L, Velasco PT, Jones BW, Fernandez SJ, Lacor PN, Horowitz P, Finch CE, Krafft GA, Klein WL (2003) Self-assembly of Abeta(1-42) into globular neurotoxins. Biochemistry 42:12749-12760.

Coleman P, Federoff H, Kurlan R (2004) A focus on the synapse for neuroprotection in Alzheimer disease and other dementias. Neurology 63:1155-1162.

Combs CK, Johnson DE, Cannady SB, Lehman TM, Landreth GE (1999) Identification of microglial signal transduction pathways mediating a neurotoxic response to amyloidogenic fragments of $\beta$-amyloid and prion proteins. J Neurosci 19:928-939.

Counts SE, Nadeem M, Lad SP, Wuu J, Mufson EJ (2006) Differential expression of synaptic proteins in the frontal and temporal cortex of elderly subjects with mild cognitive impairment. J Neuropathol Exp Neurol 65:592-601.

Dalva MB, Takasu MA, Lin MZ, Shamah SM, Hu L, Gale NW, Greenberg ME (2000) EphB receptors interact with NMDA receptors and regulate excitatory synapse formation. Cell 103:945-956.

DeKosky ST, Scheff SW (1990) Synapse loss in frontal cortex biopsies in Alzheimer's disease: correlation with cognitive severity. Ann Neurol 27:457-464.

Dodart JC, Bales KR, Gannon KS, Greene SJ, DeMattos RB, Mathis C, DeLong CA, Wu S, Wu X, Holtzman DM, Paul SM (2002) Immunization reverses memory deficits without reducing brain Abeta burden in Alzheimer's disease model. Nat Neurosci 5:452-457.

Dodd PR, Hardy JA, Oakley AE, Edwardson JA, Perry EK, Delaunoy JP (1981) A rapid method for preparing synaptosomes: comparison, with alternative procedures. Brain Res 226:107-118.

Einstein G, Buranosky R, Crain BJ (1994) Dendritic pathology of granule cells in Alzheimer's disease is unrelated to neuritic plaques. J Neurosci 14:5077-5088.

Ethell IM, Pasquale EB (2005) Molecular mechanisms of dendritic spine development and remodeling. Prog Neurobiol 75:161-205.

Ferrer I, Gullotta F (1990) Down's syndrome and Alzheimer's disease: dendritic spine counts in the hippocampus. Acta Neuropathol (Berl) 79:680-685.

Fiala JC, Spacek J, Harris KM (2002) Dendritic spine pathology: cause or consequence of neurological disorders? Brain Res Brain Res Rev 39:29-54

Futter M, Uematsu K, Bullock SA, Kim Y, Hemmings Jr HC, Nishi A, Greengard P, Nairn AC (2005) Phosphorylation of spinophilin by ERK and cyclin-dependent PK 5 (Cdk5). Proc Natl Acad Sci USA 102:3489-3494.

Georganopoulou DG, Chang L, Nam JM, Thaxton CS, Mufson EJ, Klein WL, Mirkin CA (2005) Nanoparticle-based detection in cerebral spinal fluid of a soluble pathogenic biomarker for Alzheimer's disease. Proc Natl Acad Sci USA 102:2273-2276

Gong Y, Chang L, Viola KL, Lacor PN, Lambert MP, Finch CE, Krafft GA, Klein WL (2003) Alzheimer's disease-affected brain: presence of oligomeric A beta ligands (ADDLs) suggests a molecular basis for reversible memory loss. Proc Natl Acad Sci USA 100:10417-10422.

Haes AJ, Chang L, Klein WL, Van Duyne RP (2005) Detection of a biomarker for Alzheimer's disease from synthetic and clinical samples using a nanoscale optical biosensor. J Am Chem Soc 127:2264-2271.

Harigaya Y, Shoji M, Shirao T, Hirai S (1996) Disappearance of actinbinding protein, drebrin, from hippocampal synapses in Alzheimer's disease. J Neurosci Res 43:87-92.

Harris KM, Kater SB (1994) Dendritic spines: cellular specializations imparting both stability and flexibility to synaptic function. Annu Rev Neurosci 17:341-371.

Hartley DM, Walsh DM, Ye CP, Diehl T, Vasquez S, Vassilev PM, Teplow DB, Selkoe DJ (1999) Protofibrillar intermediates of amyloid beta-protein induce acute electrophysiological changes and progressive neurotoxicity in cortical neurons. J Neurosci 19:8876-8884.

Hatanpaa K, Isaacs KR, Shirao T, Brady DR, Rapoport SI (1999) Loss of proteins regulating synaptic plasticity in normal aging of the human brain and in Alzheimer disease. J Neuropathol Exp Neurol 58:637-643.

Hering H, Lin CC, Sheng M (2003) Lipid rafts in the maintenance of syn- 
apses, dendritic spines, and surface AMPA receptor stability. J Neurosci 23:3262-3271.

Holcomb LA, Gordon MN, Jantzen P, Hsiao K, Duff K, Morgan D (1999) Behavioral changes in transgenic mice expressing both amyloid precursor protein and presenilin-1 mutations: lack of association with amyloid deposits. Behav Genet 29:177-185.

Hsia AY, Masliah E, McConlogue L, Yu GQ, Tatsuno G, Hu K, Kholodenko D, Malenka RC, Nicoll RA, Mucke L (1999) Plaque-independent disruption of neural circuits in Alzheimer's disease mouse models. Proc Natl Acad Sci USA 96:3228-3233.

Jacobsen JS, Wu CC, Redwine JM, Comery TA, Arias R, Bowlby M, Martone R, Morrison JH, Pangalos MN, Reinhart PH, Bloom FE (2006) Earlyonset behavioral and synaptic deficits in a mouse model of Alzheimer's disease. Proc Natl Acad Sci USA 103:5161-5166.

Kayed R, Head E, Thompson JL, McIntire TM, Milton SC, Cotman CW, Glabe CG (2003) Common structure of soluble amyloid oligomers implies common mechanism of pathogenesis. Science 300:486-489.

Kim H, Chae S, Lee D, Chromy B, Lee S, Park Y, Klein WL, Krafft GA, Hong S (2003) Selective neuronal degeneration induced by soluble oligomeric amyloid beta protein. FASEB J 17:118-120.

Klein WL (2002) Abeta toxicity in Alzheimer's disease: globular oligomers (ADDLs) as new vaccine and drug targets. Neurochem Int 41:345-352.

Klein WL (2006) Synaptic targeting by A $\beta$ oligomers (ADDLs) as a basis for memory loss in early Alzheimer's disease. Alzheimers Dement 2:43-55.

Klein WL, Krafft GA, Finch CE (2001) Targeting small Abeta oligomers: the solution to an Alzheimer's disease conundrum? Trends Neurosci 24:219-224.

Klein WL, Lacor PN, De Felice FG, Ferreira ST (2007) Molecules that disrupt memory circuits in Alzheimer's disease: the attack on synapses by Abeta oligomers (ADDLs). In: Memories: molecules and circuits (Bontempi B, Silva A, Christen Y, Fondation Ipsen, eds). Paris: Springer.

Kotilinek LA, Bacskai B, Westerman M, Kawarabayashi T, Younkin L, Hyman BT, Younkin S, Ashe KH (2002) Reversible memory loss in a mouse transgenic model of Alzheimer's disease. J Neurosci 22:6331-6335.

Lacor PN, Buniel MC, Chang L, Fernandez SJ, Gong Y, Viola KL, Lambert MP, Velasco PT, Bigio EH, Finch CE, Krafft GA, Klein WL (2004) Synaptic targeting by Alzheimer's-related amyloid beta oligomers. J Neurosci 24:10191-10200.

Lambert MP, Barlow AK, Chromy BA, Edwards C, Freed R, Liosatos M, Morgan TE, Rozovsky I, Trommer B, Viola KL, Wals P, Zhang C, Finch CE, Krafft GA, Klein WL (1998) Diffusible, nonfibrillar ligands derived from Abeta1-42 are potent central nervous system neurotoxins. Proc Natl Acad Sci USA 95:6448-6453.

Lambert MP, Viola KL, Chromy BA, Chang L, Morgan TE, Yu J, Venton DL, Krafft GA, Finch CE, Klein WL (2001) Vaccination with soluble Abeta oligomers generates toxicity-neutralizing antibodies. J Neurochem 79:595-605.

Lambert MP, Velasco PT, Chang L, Viola KL, Fernandez S, Lacor PN, Khuon D, Gong Y, Bigio EH, Shaw P, De Felice FG, Krafft GA, Klein WL (2007) Monoclonal antibodies that target pathological assemblies of Abeta. J Neurochem 100:23-35.

Lanz TA, Carter DB, Merchant KM (2003) Dendritic spine loss in the hippocampus of young PDAPP and Tg2576 mice and its prevention by the ApoE2 genotype. Neurobiol Dis 13:246-253.

Larson J, Lynch G, Games D, Seubert P (1999) Alterations in synaptic transmission and long-term potentiation in hippocampal slices from young and aged PDAPP mice. Brain Res 840:23-35.

Lesne S, Koh MT, Kotilinek L, Kayed R, Glabe CG, Yang A, Gallagher M, Ashe $\mathrm{KH}$ (2006) A specific amyloid-beta protein assembly in the brain impairs memory. Nature 440:352-357.

Lin H, Bhatia R, Lal R (2001) Amyloid beta protein forms ion channels: implications for Alzheimer's disease pathophysiology. FASEB J 15:2433-2444.

Lipton SA (2006) Paradigm shift in neuroprotection by NMDA receptor blockade: memantine and beyond. Nat Rev Drug Discov 5:160-170.

Lue LF, Kuo YM, Roher AE, Brachova L, Shen Y, Sue L, Beach T, Kurth JH, Rydel RE, Rogers J (1999) Soluble amyloid beta peptide concentration as a predictor of synaptic change in Alzheimer's disease. Am J Pathol 155:853-862.

Masliah E, Mallory M, Alford M, DeTeresa R, Hansen LA, McKeel Jr DW, Morris JC (2001) Altered expression of synaptic proteins occurs early during progression of Alzheimer's disease. Neurology 56:127-129.
Matus A (2000) Actin-based plasticity in dendritic spines. Science 290:754-758.

Matynia A, Kushner SA, Silva AJ (2002) Genetic approaches to molecular and cellular cognition: a focus on LTP and learning and memory. Annu Rev Genet 36:687-720.

Mishizen-Eberz AJ, Rissman RA, Carter TL, Ikonomovic MD, Wolfe BB, Armstrong DM (2004) Biochemical and molecular studies of NMDA receptor subunits $\mathrm{NR} 1 / 2 \mathrm{~A} / 2 \mathrm{~B}$ in hippocampal subregions throughout progression of Alzheimer's disease pathology. Neurobiol Dis 15:80-92.

Mokin M, Lindahl JS, Keifer J (2006) Immediate-early gene-encoded protein Arc is associated with synaptic delivery of GluR4-containing AMPA receptors during in vitro classical conditioning. J Neurophysiol 95:215-224.

Moolman DL, Vitolo OV, Vonsattel JP, Shelanski ML (2004) Dendrite and dendritic spine alterations in Alzheimer models. J Neurocytol 33:377-387.

Morris RGM, Davis M (1994) The role of NMDA receptors in learning and memory. In: The NMDA receptor (Collingridge GL, Watkins JC, eds), pp 340-375. Oxford: Oxford UP.

Mucke L, Masliah E, Yu GQ, Mallory M, Rockenstein EM, Tatsuno G, Hu K, Kholodenko D, Johnson-Wood K, McConlogue L (2000) High-level neuronal expression of abeta 1-42 in wild-type human amyloid protein precursor transgenic mice: synaptotoxicity without plaque formation. J Neurosci 20:4050-4058.

Mukaetova-Ladinska EB, Garcia-Siera F, Hurt J, Gertz HJ, Xuereb JH, Hills R, Brayne C, Huppert FA, Paykel ES, McGee M, Jakes R, Honer G, Harrington CR, Wischik CM (2000) Staging of cytoskeletal and $\beta$-amyloid changes in human isocortex reveals biphasic synaptic protein response during progression of Alzheimer's disease. Am J Pathol 157:623-636.

Oddo S, Caccamo A, Smith IF, Green KN, LaFerla FM (2006a) A dynamic relationship between intracellular and extracellular pools of Abeta. Am J Pathol 168:184-194.

Oddo S, Caccamo A, Tran L, Lambert MP, Glabe CG, Klein WL, LaFerla FM (2006b) Temporal profile of amyloid-beta (Abeta) oligomerization in an in vivo model of Alzheimer disease. A link between Abeta and tau pathology. J Biol Chem 281:1599-1604.

Ohno M, Chang L, Tseng W, Oakley H, Citron M, Klein WL, Vassar R, Disterhoft JF (2006) Temporal memory deficits in Alzheimer's mouse models: rescue by genetic deletion of BACE1. Eur J Neurosci 23:251-260.

Okamoto K, Nagai T, Miyawaki A, Hayashi Y (2004) Rapid and persistent modulation of actin dynamics regulates postsynaptic reorganization underlying bidirectional plasticity. Nat Neurosci 7:1104-1112.

Phillips GR, Huang JK, Wang Y, Tanaka H, Shapiro L, Zhang W, Shan WS, Arndt K, Frank M, Gordon RE, Gawinowicz MA, Zhao Y, Colman DR (2001) The presynaptic particle web: ultrastructure, composition, dissolution, and reconstitution. Neuron 32:63-77.

Raiteri L, Raiteri M (2000) Synaptosomes still viable after 25 years of superfusion. Neurochem Res 25:1265-1274.

Rodgers AB (2005) Progress report on Alzheimer's disease 2004-2005: new discoveries, new insights. Washington, DC:United States Department of Health and Human Services.

Scheff SW, Price DA (2003) Synaptic pathology in Alzheimer's disease: a review of ultrastructural studies. Neurobiol Aging 24:1029-1046.

Scheibel AB (1983) Dendritic changes. In: Alzheimer's disease (Reisberg B, ed), pp 69-73. New York: The Free Press.

Segal M (2005) Dendritic spines and long-term plasticity. Nat Rev Neurosci 6:277-284.

Sekino Y, Tanaka S, Hanamura K, Yamazaki H, Sasagawa Y, Xue Y, Hayashi $\mathrm{K}$, Shirao T (2006) Activation of $N$-methyl-D-aspartate receptor induces a shift of drebrin distribution: disappearance from dendritic spines and appearance in dendritic shafts. Mol Cell Neurosci 31:493-504.

Selkoe DJ (2002) Alzheimer's disease is a synaptic failure. Science 298:789-791.

Sheng M (2001) Molecular organization of the postsynaptic specialization. Proc Natl Acad Sci USA 98:7058-7061.

Shim KS, Lubec G (2002) Drebrin, a dendritic spine protein, is manifold decreased in brains of patients with Alzheimer's disease and Down syndrome. Neurosci Lett 324:209-212.

Snyder EM, Nong Y, Almeida CG, Paul S, Moran T, Choi EY, Nairn AC, Salter MW, Lombroso PJ, Gouras GK, Greengard P (2005) Regulation of NMDA receptor trafficking by amyloid-beta. Nat Neurosci 8:1051-1058.

Spires TL, Meyer-Luehmann M, Stern EA, McLean PJ, Skoch J, Nguyen PT, Bacskai BJ, Hyman BT (2005) Dendritic spine abnormalities in amyloid 
precursor protein transgenic mice demonstrated by gene transfer and intravital multiphoton microscopy. J Neurosci 25:7278-7287.

Standridge JB (2006) Vicious cycles within the neuropathophysiologic mechanisms of Alzheimer's disease. Curr Alzheimer Res 3:95-108.

Sze C, Bi H, Kleinschmidt-DeMasters BK, Filley CM, Martin LJ (2001) $\mathrm{N}$-Methyl-D-aspartate receptor subunit proteins and their phosphorylation status are altered selectively in Alzheimer's disease. J Neurol Sci 182:151-159.

Sze CI, Troncoso JC, Kawas C, Mouton P, Price DL, Martin LJ (1997) Loss of the presynaptic vesicle protein synaptophysin in hippocampus correlates with cognitive decline in Alzheimer disease. J Neuropathol Exp Neurol 56:933-944.

Takahashi H, Sekino Y, Tanaka S, Mizui T, Kishi S, Shirao T (2003) Drebrin-dependent actin clustering in dendritic filopodia governs synaptic targeting of postsynaptic density-95 and dendritic spine morphogenesis. J Neurosci 23:6586-6595.

Terry RD, Masliah E, Salmon DP, Butters N, DeTeresa R, Hill R, Hansen LA, Katzman R (1991) Physical basis of cognitive alterations in Alzheimer's disease: synapse loss is the major correlate of cognitive impairment. Ann Neurol 30:572-580.

Tong L, Thornton PL, Balazs R, Cotman CW (2001) Beta-amyloid-(1-42) impairs activity-dependent cAMP-response element-binding protein sig- naling in neurons at concentrations in which cell survival is not compromised. J Biol Chem 276:17301-17306.

Torres R, Firestein BL, Dong H, Staudinger J, Olson EN, Huganir RL, Bredt DS, Gale NW, Yancopoulos GD (1998) PDZ proteins bind, cluster, and synaptically colocalize with Eph receptors and their ephrin ligands. Neuron 21:1453-1463.

Townsend M, Shankar GM, Mehta T, Walsh DM, Selkoe DJ (2006) Effects of secreted oligomers of amyloid beta-protein on hippocampal synaptic plasticity: a potent role for trimers. J Physiol (Lond) 572:477-492.

Walsh DM, Selkoe DJ (2004) Deciphering the molecular basis of memory failure in Alzheimer's disease. Neuron 44:181-193.

Wang HW, Pasternak JF, Kuo H, Ristic H, Lambert MP, Chromy B, Viola KL, Klein WL, Stine WB, Krafft GA, Trommer BL (2002) Soluble oligomers of beta amyloid (1-42) inhibit long-term potentiation but not long-term depression in rat dentate gyrus. Brain Res 924:133-140.

Ying SW, Futter M, Rosenblum K, Webber MJ, Hunt SP, Bliss TV, Bramham CR (2002) Brain-derived neurotrophic factor induces long-term potentiation in intact adult hippocampus: requirement for ERK activation coupled to CREB and upregulation of Arc synthesis. J Neurosci 22:1532-1540.

Zito K, Knott G, Shepherd GM, Shenolikar S, Svoboda K (2004) Induction of spine growth and synapse formation by regulation of the spine actin cytoskeleton. Neuron 44:321-334. 